\title{
Identification of the Paleocene-Eocene boundary in coastal strata in the Otway Basin, Victoria, Australia
}

\author{
Joost Frieling ${ }^{1}$, Emiel P. Huurdeman ${ }^{1}$, Charlotte C. M. Rem ${ }^{1}$, Timme H. Donders ${ }^{2}$, Jörg Pross ${ }^{3}$, \\ Steven M. Bohaty ${ }^{4}$, Guy R. Holdgate ${ }^{5}$, Stephen J. Gallagher ${ }^{5}$, Brian McGowran ${ }^{6}$, and Peter K. Bijl ${ }^{1}$ \\ ${ }^{1}$ Marine Palynology and Paleoceanography, Laboratory of Palaeobotany and Palynology, Department of Earth \\ Sciences, Faculty of Geosciences, Utrecht University, Heidelberglaan 2, 3584CS, Utrecht, the Netherlands \\ ${ }^{2}$ Palaeoecology, Laboratory of Palaeobotany and Palynology, Department of Physical Geography, \\ Faculty of Geosciences, Utrecht University, Heidelberglaan 2, 3584CS, Utrecht, the Netherlands \\ ${ }^{3}$ Paleoenvironmental Dynamics Group, Institute of Earth Sciences, Heidelberg \\ University, Im Neuenheimer Feld 234, 69120 Heidelberg, Germany \\ ${ }^{4}$ Ocean and Earth Science, National Oceanography Centre \\ Southampton, University of Southampton, Southampton, UK \\ ${ }^{5}$ School of Earth Sciences, The University of Melbourne, Melbourne, Australia \\ ${ }^{6}$ Department of Earth Sciences, The University of Adelaide, Adelaide, Australia
}

Correspondence: Joost Frieling (j.frieling1@uu.nl)

Received: 25 September 2017 - Revised: 12 January 2018 - Accepted: 18 January 2018 - Published: 13 February 2018

Abstract. Detailed, stratigraphically well-constrained environmental reconstructions are available for Paleocene and Eocene strata at a range of sites in the southwest Pacific Ocean (New Zealand and East Tasman Plateau; ETP) and Integrated Ocean Discovery Program (IODP) Site U1356 in the south of the Australo-Antarctic Gulf (AAG). These reconstructions have revealed a large discrepancy between temperature proxy data and climate models in this region, suggesting a crucial error in model, proxy data or both. To resolve the origin of this discrepancy, detailed reconstructions are needed from both sides of the Tasmanian Gateway. Paleocene-Eocene sedimentary archives from the west of the Tasmanian Gateway have unfortunately remained scarce (only IODP Site U1356), and no well-dated successions are available for the northern sector of the AAG. Here we present new stratigraphic data for upper Paleocene and lower Eocene strata from the Otway Basin, southeast Australia, on the (north)west side of the Tasmanian Gateway. We analyzed sediments recovered from exploration drilling (Latrobe-1 drill core) and outcrop sampling (Point Margaret) and performed high-resolution carbon isotope geochemistry of bulk organic matter and dinoflagellate cyst (dinocyst) and pollen biostratigraphy on sediments from the regional lithostratigraphic units, including the Pebble Point Formation, Pember Mudstone and Dilwyn Formation. Pollen and dinocyst assemblages are assigned to previously established Australian pollen and dinocyst zonations and tied to available zonations for the SW Pacific. Based on our dinocyst stratigraphy and previously published planktic foraminifer biostratigraphy, the Pebble Point Formation at Point Margaret is dated to the latest Paleocene. The globally synchronous negative carbon isotope excursion that marks the Paleocene-Eocene boundary is identified within the top part of the Pember Mudstone in the Latrobe-1 borehole and at Point Margaret. However, the high abundances of the dinocyst Apectodinium prior to this negative carbon isotope excursion prohibit a direct correlation of this regional bio-event with the quasi-global Apectodinium acme at the PaleoceneEocene Thermal Maximum (PETM; 56 Ma). Therefore, the first occurrence of the pollen species Spinizonocolpites prominatus and the dinocyst species Florentinia reichartii are here designated as regional markers for the PETM. In the Latrobe-1 drill core, dinocyst biostratigraphy further indicates that the early Eocene ( $\sim 56-51 \mathrm{Ma})$ sediments are truncated by a $\sim 10 \mathrm{Myr}$ long hiatus overlain by middle Eocene $(\sim 40 \mathrm{Ma})$ strata. These sedimentary archives from southeast Australia may prove key in resolving the model-data discrepancy in this region, and the new stratigraphic data presented here allow for detailed comparisons between paleoclimate records on both sides of the Tasmanian Gateway. 


\section{Introduction}

\subsection{General introduction}

Both marine (Bijl et al., 2009; Hollis et al., 2009) and terrestrial (Carpenter et al., 2012; Contreras et al., 2014; Macphail et al., 1994) temperature proxy records suggest that the midlatitude to high-latitude southwest Pacific was extremely warm $\left(25-35^{\circ} \mathrm{C}\right)$ during the warmest intervals of the late Paleocene, Paleocene-Eocene Thermal Maximum (PETM; $56 \mathrm{Ma})$ and early Eocene, yielding a substantial mismatch between proxy data and climate-model output for this region that is yet unresolved (Hollis et al., 2012). The anomalously high temperatures may have partly resulted from large-scale tectonic changes such as the opening of the Tasmanian Gateway, and it has been hypothesized that this gateway played an important role in diverting ocean currents and influencing climate on a regional scale (Bijl et al., 2013a; Sijp et al., 2016, 2014, 2011) and beyond (e.g., Kennett, 1977). Importantly, the Australo-Antarctic Gulf (AAG), including the Otway Basin, to the west of the gateway is expected to have been under the influence of warm, low-latitude currents during the late Paleocene and early Eocene, whereas the SW Pacific on the eastern side of the gateway was more influenced by cooler, high-latitude-derived waters (Bijl et al., 2011; Holdgate et al., 2017) (see also Fig. 1a). Presently, however, most available climate data covering the late $\mathrm{Pa}$ leocene and early Eocene are derived from sites east of the Tasmanian Gateway (Bijl et al., 2010, 2009; Hollis et al., 2015, 2009; Sluijs et al., 2011), with the notable exception of Integrated Ocean Drilling Program (IODP) Site U1356 in the south of the AAG (Bijl et al., 2013a; Pross et al., 2012). Sedimentary archives from the northwest side of the Tasmanian Gateway, such as those from the Otway Basin, southeast Australia, allow further assessment of the influence of a closed Tasmanian Gateway on regional climate evolution. However, sediments from the Otway Basin require a highresolution stratigraphic framework before regional paleoenvironmental records can be compared. The aim of this paper is the establishment of such a framework through integrated terrestrial and marine palynology and isotope stratigraphy.

\subsection{Otway Basin}

The Otway Basin consists of several east-west-oriented troughs on the northwestern side of the Tasmanian Gateway. It borders the Bass and Gippsland basins to the east and the Murray Basin to the northwest (Gallagher and Holdgate, 2000; Holdgate and Gallagher, 2003). The formation of the Otway Basin is related to the breakup between Australia and Antarctica, starting in the late Cretaceous (Cande and Stock, 2004). Extensive deposits were formed in the Otway Basin during post-rift subsidence in the Cenozoic with several depositional centers. During the early Paleogene, the deposi- tional center was located close to the present-day shoreline (Gallagher and Holdgate, 2000). The Wangerrip Group of the Otway Basin consists of Paleocene and Eocene strata, which overlie the upper Cretaceous Sherbrook Group or unconformably overlie the lower Cretaceous Otway Group in the shallower parts of the basin (see Fig. 2 for a schematic overview of regional lithological units and Holdgate and Gallagher, 2003, for a detailed overview of the regional Cenozoic geology). Wire line logs and seismic analyses show that up to $1000 \mathrm{~m}$ of Wangerrip Group sediments accumulated in the Portland Trough in the deeper, western parts of the Otway Basin (e.g., Holdgate et al., 2003). Closer to the (paleo-)shore, sediment thickness is substantially reduced, spanning $\sim 360 \mathrm{~m}$ for the entire Wangerrip Group in the Latrobe-1 drill core (Arditto, 1995) and even less in the outcrop sections along the coast.

Arditto (1995) further subdivided the Wangerrip Group into eight third-order transgressive-regressive sequences, the lowermost of which, the Pember Mudstone, represents the transgression from the Pebble Point Formation to the Dilwyn Formation. Lithologically, the Pebble Point Formation is characterized by meter-scale mud-to-sandstone alternations interpreted to represent high-energy, shallow-marine environments (e.g., Keating, 1993). The Pebble Point Formation is further divided into three lithostratigraphic units, the Margaret (bottom), Buckley and Cobble Cove (top) members (Keating, 1993; Holdgate and Gallagher, 2003). The homogeneous silty claystones of the Pember Mudstone overlie the Cobble Cove member. Several other, younger, distinct units are recognized within the Dilwyn Formation, including the Rivernook-A and Rivernook beds consisting of glauconitic sandstones. Together with thin macrofossil-bearing intervals designated as "Trochocyathus" and "Turritella" beds, the Rivernook beds are useful for regional correlations (e.g., Baker, 1953, 1950).

\subsection{Previous stratigraphic efforts}

Several pronounced marine ingressions, ranging in age from Maastrichtian to Eocene, have been identified in the composite sedimentary succession for southern Australia, representing the northern neritic flank of the AAG (McGowran, 1991, 1978; McGowran et al., 2004). The ingressions are named as follows: Ceduna (Maastrichtian in age), Kings Park (late Selandian), Pebble Point (late Thanetian), RivernookA and Rivernook (earliest Ypresian), and Princetown and Burrungule (Ypresian). The oldest Paleogene sediments in the Otway Basin are assigned to the Pebble Point Formation (Holdgate and Gallagher, 2003). The calcareous macro(Eglington, 2006; Stilwell, 2003) and microfossils (McGowran, 1970, 1965; Taylor, 1964) from the marine ingressions in the Otway Basin have allowed low-resolution correlation with regional and global biostratigraphic zonal schemes. 


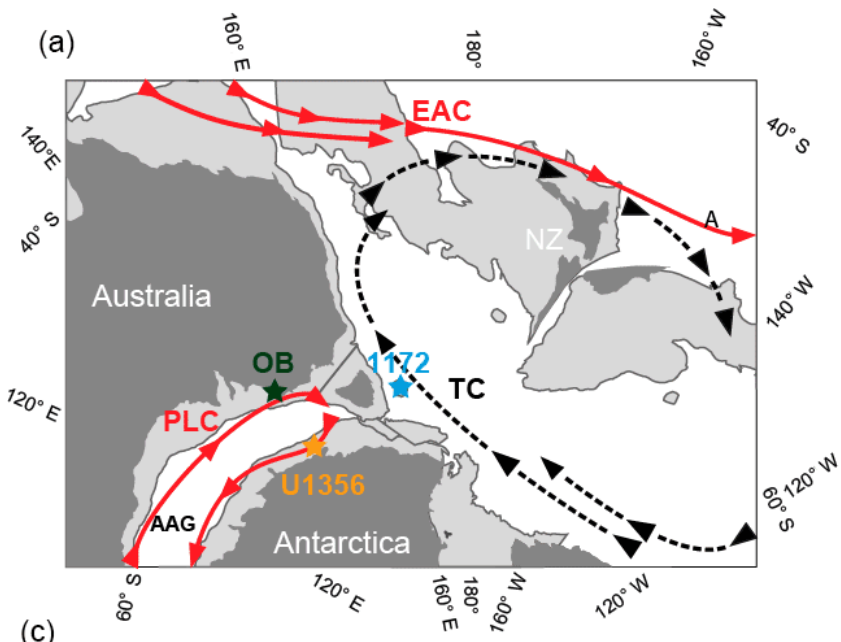

(b)
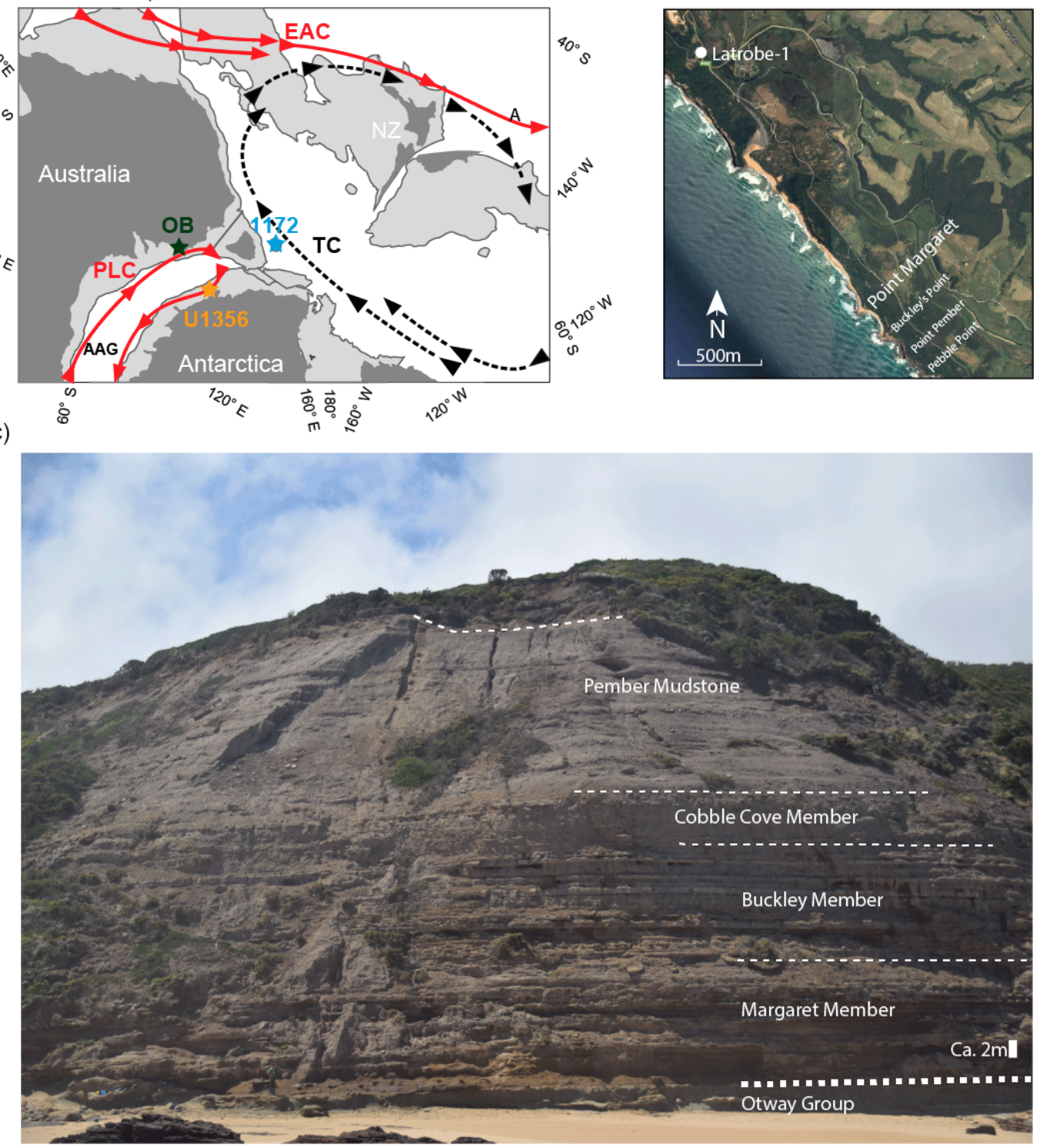

Figure 1. (a) Paleogeographic reconstruction for the early Eocene ( 54 Ma), redrawn from Bijl et al. (2013a). The Latrobe-1 and Point Margaret are located at the green star in the Otway Basin (OB). Abbreviations: AAG - Australo-Antarctic Gulf; PLC - Proto-Leeuwin Current; TC - Tasman Current; EAC - East Australia Current; NZ - New Zealand. (b) Satellite image (Google Earth) of the study area (ca. $3 \mathrm{~km} \times 3 \mathrm{~km} ; \sim 38^{\circ} 42^{\prime} \mathrm{S}, 143^{\circ} 10^{\prime} \mathrm{E}$ ), indicating the location of Latrobe-1 and Point Margaret outcrop, as well as nearby outcrop sections mentioned in text. (c) Face of the Point Margaret outcrop; see bottom right for scale; dashed lines indicate approximate boundaries of the different lithological units (for detailed lithological log, see Fig. 4); photo by Peter K. Bijl.

The Burrungule Member ingression of the Dilwyn Formation represents the highest known Ypresian stratum in the Otway Basin. There is no biostratigraphic evidence anywhere in the AAG for the interval between latest Ypresian and latest Lutetian; this well-documented hiatus is known as the "Lutetian gap" ( 50-42 Ma) (Holdgate and Gallagher, 2003; McGowran et al., 2004). In the Otway Basin the oldest overlying strata are the middle Eocene Mepunga Formation (ca. $42 \mathrm{Ma}$ ) of the Nirranda Group.
Pollen and dinoflagellate cyst biostratigraphy has been instrumental in detailed correlations of these marginal marine formations within the Otway Basin and with other southern Australian basins (Harris, 1971; Partridge, 1999). The Pebble Point Formation, Pember Mudstone and Dilwyn Formation were previously dated as middle or late Paleocene to early Eocene in age based on planktonic foraminifera, pollen, spore and dinocyst assemblages (Harris, 1971; McGowran, 1965; Partridge, 1999; Taylor, 1965, 1964). 


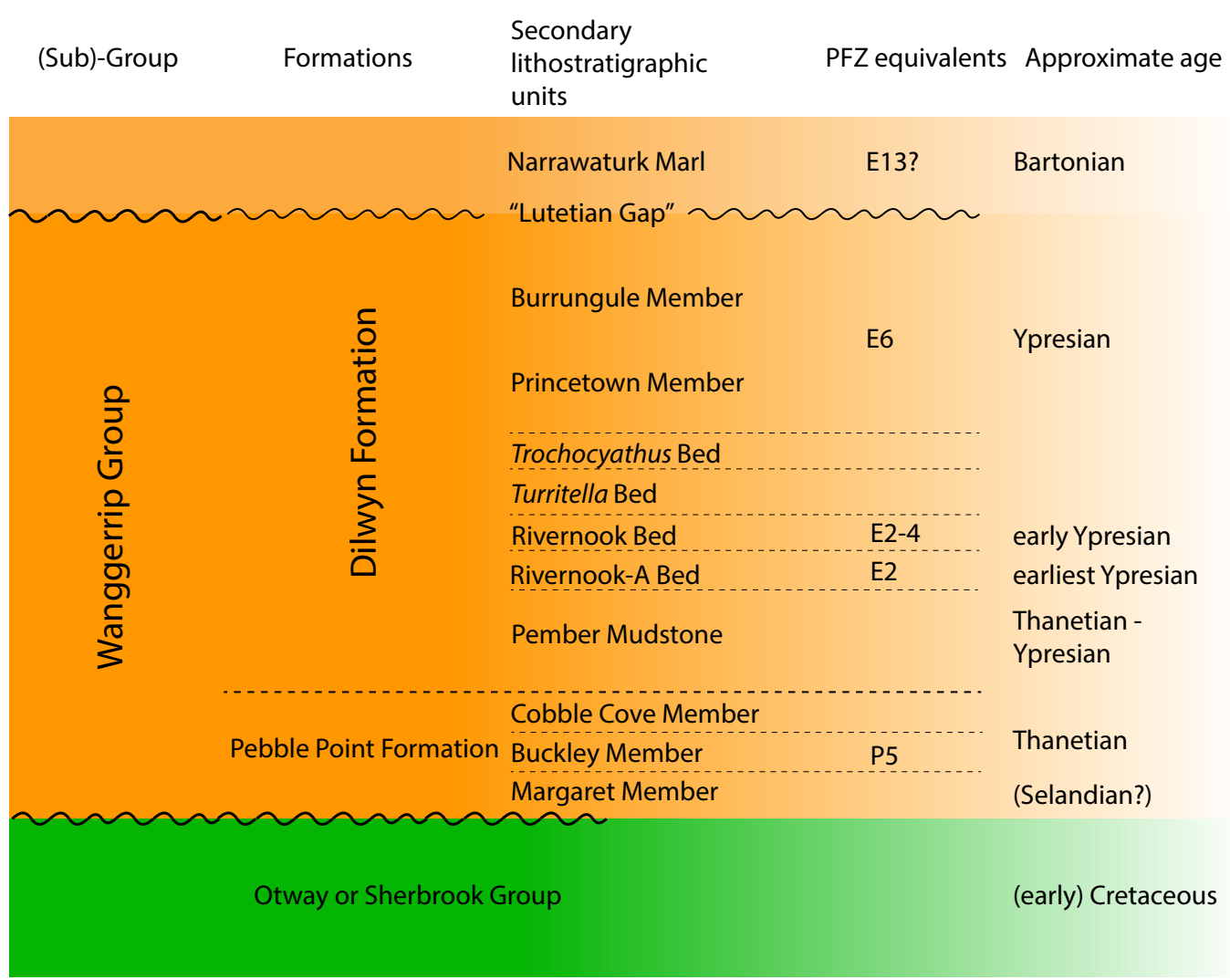

Figure 2. Schematic overview of regional lithostratigraphic units and their approximate ages (see McGowran et al., 2004, for a detailed overview). Relative thickness of lithological units is not to scale. PFZ: planktonic foraminifer zone. Absolute ages in million years ago (Ma); tie points derived from previous work are marked with *.

Foraminifera and calcareous macrofossils in the Pebble Point Formation are largely restricted to the Buckley and lower Cobble Cove members (Holdgate and Gallagher, 2003; Keating, 1993). The key planktonic foraminifer is Globanomalina australiformis in the Buckley Member, Pebble Point Formation (McGowran, 1965). G. australiformis is younger than and does not biostratigraphically overlap with Globanomalina pseudomenardii. The last occurrence (LO) of G. pseudomenardii defines the base of planktonic foraminifer zone (PFZ) P5 (57.1-56 Ma; Wade et al., 2011) at about the magnetochron $\mathrm{C} 25 \mathrm{n}-\mathrm{C} 24 \mathrm{r}$ boundary $(\sim 57.1 \mathrm{Ma})$ (Berggren and Pearson, 2005), approximately $\sim 1.1 \mathrm{Myr}$ before the PETM ( $\sim 56 \mathrm{Ma})$ (Gradstein et al., 2012). In the Southern Ocean the first occurrence (FO) of G. australiformis is within the early part of $\mathrm{C} 24 \mathrm{r}$ and in the top part of PFZ P5, below the carbon isotope excursion that marks the PETM (Berggren and Pearson, 2005; Huber and Quillévéré, 2005). The FO of G. australiformis is thus estimated to be no older than $\sim 56.5 \mathrm{Ma}$. It should be noted that the FO of G. australiformis can be confidently placed after the PETM and the quasi-global Apectodinium acme in New Zealand (Crouch et al., 2001; Morgans et al., 2004), evidence of the biogeographical barrier the Tasmanian Gateway represents.
Planktonic foraminiferal species identified in the Rivernook-A Bed (Dilwyn Formation) higher in the sequence include Globanomalina luxorensis, G. australiformis, Subbotina patagonica, Morozovella aequa, rare M. acuta, Acarinina wilcoxensis and A. esnaensis (McGowran, 1965). The co-occurrence of Globanomalina luxorensis and Morozovella aff. acuta correlates RivernookA with PFZ E2 ( 55.9-55.1 Ma) (Wade et al., 2011). The presence of Morozovella acuta implies the Rivernook-A ingression is no younger than $\sim 55.3 \mathrm{Ma}$ (Wade et al., 2011).

The Rivernook assemblage contains the highest relative abundance of planktonic foraminifera of any assemblage in the neritic Ypresian in the AAG. The diverse assemblage includes, amongst others, Morozovella aequa and Acarinina esnaensis (McGowran, 1965). The co-occurrence of abundant Acarinina esnaensis and common and well-developed Morozovella aequa is characteristic of early Eocene PFZ E2 to lower E4 (55.8-54.6 Ma) (Wade et al., 2011).

Using samples dredged from the edge of the Ceduna Plateau (northern AAG, $\sim 35^{\circ} \mathrm{S}, 132^{\circ} \mathrm{E}$ ) as proxies for the often poorly preserved Princetown and Burrungule foraminiferal faunas, McGowran (1991) estimated that the Princetown and Burrungule ingressions were late Ypresian in 


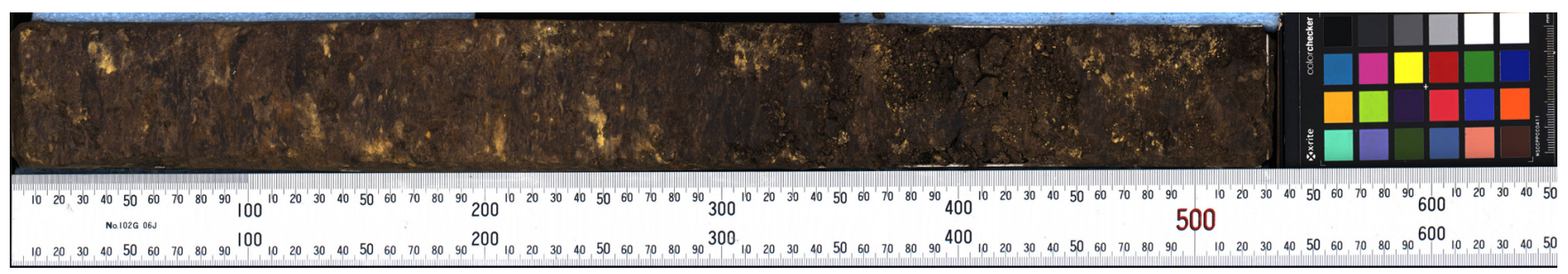

Figure 3. Casing used for continuous sampling of the upper Pember Mudstone at Point Margaret. Photo of a casing (no. 27; 47.63-48.16 m stratigraphic height) including an X-Rite color checker (right). Scale below in millimeters.

age, roughly equivalent to PFZ E6 (51.3-50.8 Ma). However, this inference is based on the absence of Acarinina primitiva. The FO of A. primitiva in the Austral realm west of the AAG was determined as earliest C22n ( $\sim 48 \mathrm{Ma})$ (Huber and Quillévéré, 2005).

The existing stratigraphic assessment suggests the presence of extensive late Paleocene to early Eocene deposits in the Otway Basin (Fig. 2). However, detailed correlation with sites on the east side of the Tasmanian Gateway remains challenging due to the small number of tie points and diachroneity in bio-events due to a closed Tasmanian Gateway.

\subsection{Aims and approach}

Carbon isotope chemo-stratigraphy represents a powerful stratigraphic tool for the Paleogene. It allows marking the position of several transient (10-100 kyr scale) climate events in the Paleocene and Eocene with great confidence (e.g., Lourens et al., 2005; Nicolo et al., 2007). The largest of these events, the PETM (56 Ma) is marked by a globally synchronous 2-8\%o negative carbon isotope excursion (CIE) (Kennett and Stott, 1991; McInerney and Wing, 2011), the magnitude of which depends on the sample substrate and post-depositional (diagenetic) effects. Furthermore, the PETM CIE has a distinct shape, consisting of a very rapid onset (1-5 kyr) (Kirtland Turner and Ridgwell, 2016; Zeebe et al., 2016) and a prolonged plateau phase termed the "body" (70-100 kyr) followed by a gradual recovery $(\sim 100 \mathrm{kyr})$ (Abdul Aziz et al., 2008; Murphy et al., 2010; Röhl et al., 2007). Subsequent events in the early Eocene, such as the Eocene Thermal Maximum (ETM) $2(\sim 54 \mathrm{Ma}$; Lourens et al., 2005) and ETM3 ( 52.5 Ma; Agnini et al., 2009) are typified by smaller CIEs and lack a plateau phase.

To date, stable carbon isotope chemo-stratigraphy has not yet been established for the sedimentary successions of the Otway Basin. In addition, high-resolution carbon isotope analyses may allow a detailed assessment of the completeness of the sedimentary archives. Therefore, to refine regional stratigraphy and set the stage for further highresolution paleoclimate studies, we here combine carbon isotope chemo-stratigraphy with pollen and dinocyst biostratigraphy to date the Paleocene and Eocene from the Latrobe-1 core and dinocyst biostratigraphy from the Point Margaret outcrop section (Fig. 1).

\section{Material and methods}

\subsection{Material}

\subsubsection{Point Margaret coastal outcrop}

We targeted coastal outcrops of the Pebble Point Formation and Pember Mudstone at Point Margaret (coordinates: $38^{\circ} 43^{\prime} 28.8^{\prime \prime} \mathrm{S}, 143^{\circ} 10^{\prime} 35.0^{\prime \prime} \mathrm{E}$; Fig. 1) for high-resolution sampling. Point Margaret is situated northwest of Pebble Point and $\sim 3 \mathrm{~km}$ to the southeast of the Latrobe- 1 borehole (Fig. 1b). Pebble Point is the type section for the Pebble Point Formation; and the only formally named geographical location (Point Margaret, Buckley's Point and Point Pember are all informal names from Baker, 1950). We logged and sampled the Point Margaret outcrop (Fig. 4) during a field expedition in February 2016. Fine-grained, organic-rich strata in the Pebble Point Formation were preferentially sampled to optimize palynological yield. A total of 365 discrete samples were taken: 57 from the Pebble Point Formation and 308 from the Pember Mudstone.

In addition, the uppermost $\sim 17 \mathrm{~m}$ of the outcrop were sampled continuously using 35 stainless-steel casings (Fig. 3), each measuring $53 \mathrm{~cm} \times 5 \mathrm{~cm} \times 3 \mathrm{~cm}$ (length $\times$ width $\times$ depth), that were hammered into a thoroughly cleaned part of the section with $1-2 \mathrm{~cm}$ overlap. The uppermost part of the Pember Mudstone and the overlying Rivernook beds are not exposed or missing in the Point Margaret outcrop. All heights are given in meters of stratigraphic height above the base of the outcrop, measured along the face of the outcrop. The base of the logged section may be covered by beach sands in the future; in this case, the contact between the glauconitic sands of the Otway Group and the Pebble Point Formation at $1.7 \mathrm{~m}$ can be used as a secondary calibration point (Fig. 1c). The outcrop is nearly vertical in the Pebble Point Formation and $60-75^{\circ}$ steep in the Pember Mudstone. This change in slope angle implies that we have likely overestimated $(5-15 \%)$ the thickness of the Pember Mudstone relative to that of the Pebble Point Formation. 


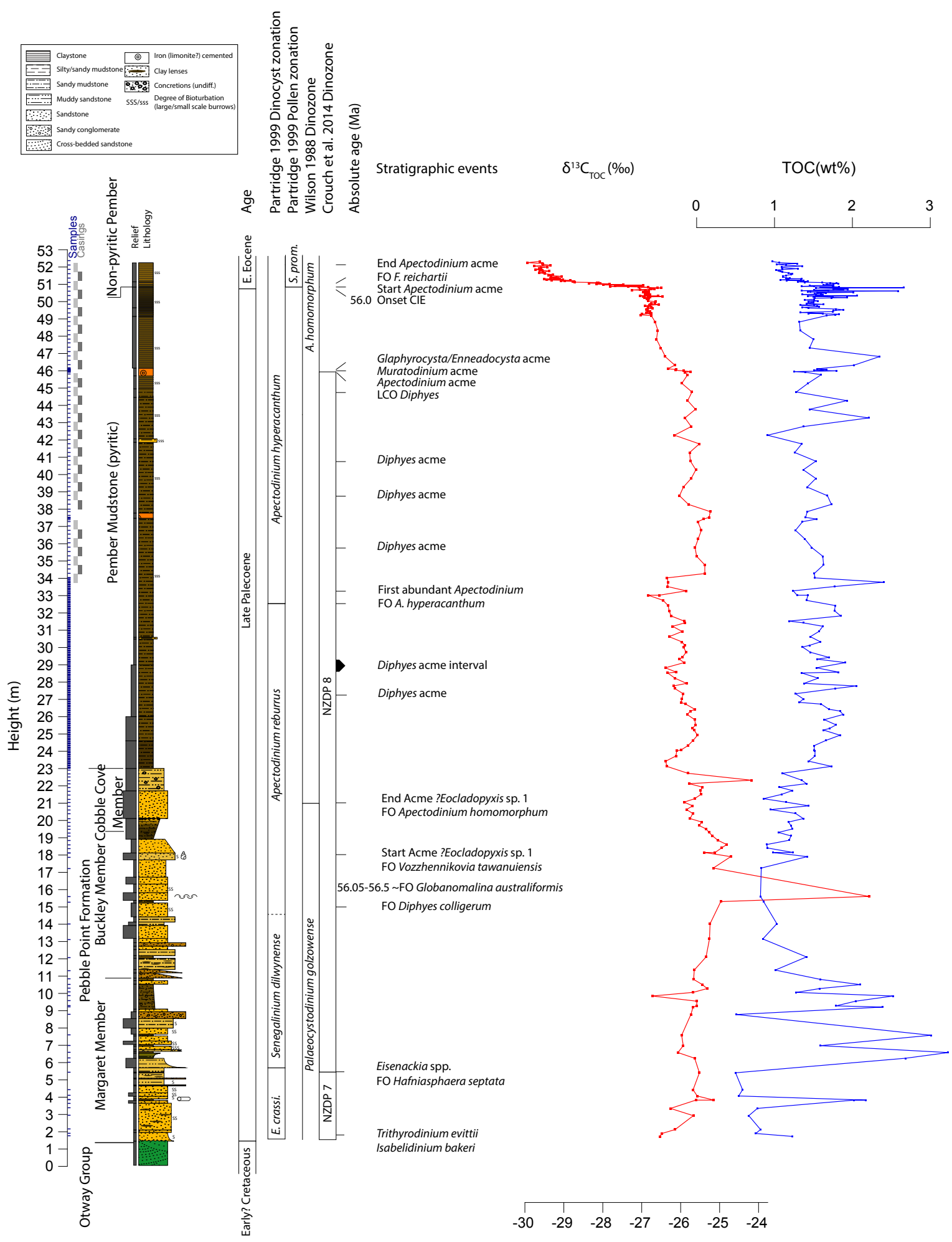

Figure 4. Stratigraphy of the Point Margaret section. Main lithostratigraphic units are indicated, as are all sample positions, relief, lithology and the dinocyst zonations of Partridge (1999), Wilson (1988) and Crouch et al. (2014). Colors in the lithological column are used to indicate approximate sediment coloring. Important local bio-events are also given. Carbon isotope values of bulk organic matter are given in per mill versus (Vienna) Pee Dee Belemnite (VPDB) (\%o); total organic carbon (TOC) content of the sediment is given in weight \% (wt \%). Abbreviations: Eisenackia crassitabulata - E. crassi.; Spinizonocolpites prominatus - S. prom. 


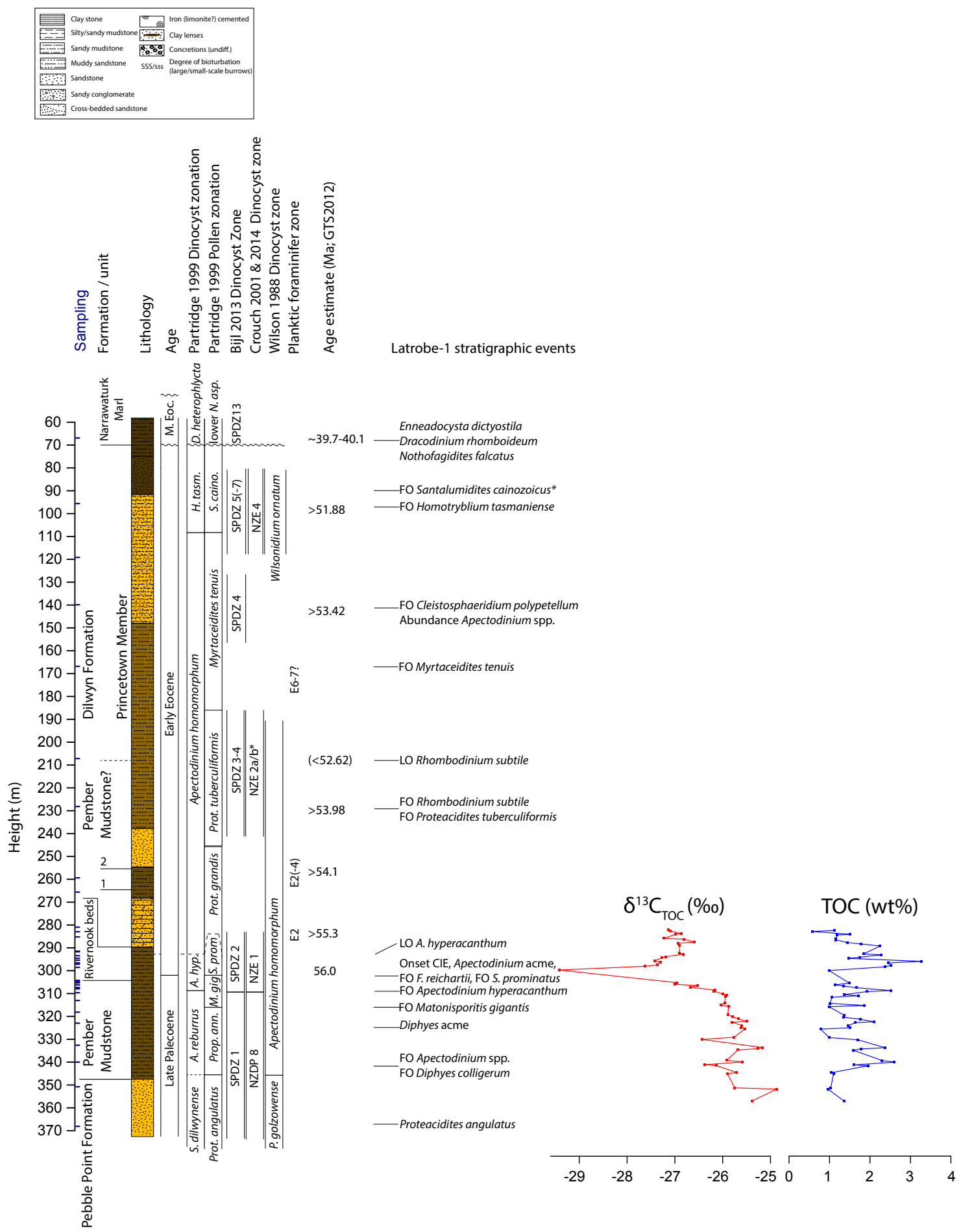

Figure 5. Stratigraphy of the Latrobe-1 borehole. Basic lithostratigraphic units are indicated, as are all sample positions, lithology, dinocyst and pollen zonations of Partridge (1999) and dinocyst zonations of Wilson (1988), Bijl et al. (2013b) and Crouch et al. (2014). Colors in the lithological column are used to indicate approximate sediment coloring. Important local bio-events and, where available, absolute age tie points are also given. Carbon isotope values of bulk organic matter are given in per mill versus PDB (\%o); total organic carbon (TOC) content of the decalcified sediment is given in weight \% (wt \%). Dinocyst zone name abbreviations: Senegalinium dilwynense - S. dilwynense; Vozzhennikovia cf. tawanuiensis - V. cf. tawa.; Apectodinium hyperacanthum - A. hyperacanthum; Homotryblium tasmaniense - H. tasmaniense; Achilleodinium biformoides - Ach. biform. Pollen zone abbreviations: Proteacidites - Prot.; Propyllipollis - Prop.; Matonisporites gigantis - M. gig.; Spinizonocolpites prominatus - S. prom.; Santalumidites cainozoicus - S. caino (* note that the FO of S. cainozoicus is from Archer, 1977); Nothofagidites asperus - N. asp. 


\subsubsection{Latrobe-1 core}

The Latrobe-1 core (coordinates: $38^{\circ} 41^{\prime} 35^{\prime \prime} \mathrm{S}$, $143^{\circ} 09^{\prime} 00^{\prime \prime} \mathrm{E}$; Fig. 1) was drilled in 1963 and cored to a depth of $626 \mathrm{~m}$. Although there is no continuous recovery, logging data are available for the entire hole (White, 1963) and enable the evaluation of the complete succession as well as correlation with other wells in the region (Holdgate and Gallagher, 2003). We took a total of 106 samples from core sections AK to CU (61.46-385.15 m below surface; mb.s.) representing, amongst others, the Pebble Point Formation, Pember Mudstone, Dilwyn Formation and Narrawaturk Marl (Fig. 5). The cores were partially severely dried out and crumbly, hampering the accurate placement of our samples within the core sections. Stratigraphic information was derived from available low-resolution foraminiferal biostratigraphy (Taylor, 1964) and wire line log data (White, 1963). We sampled the Pember Mudstone at a slightly higher $(\sim 1 \mathrm{~m})$ resolution, although core recovery is poor $(<10 \%)$ in some intervals. We converted core depth intervals and core log data from feet to meters, and calculated depth within core sections assuming that recovered sediments originated from the top of the cored interval.

\subsection{Methods}

\subsubsection{Total organic carbon and carbon isotope analyses}

Total organic carbon (TOC) measurements and bulk organic carbon isotope analyses $\left(\delta^{13} \mathrm{C}_{\mathrm{TOC}}\right)$ were conducted on 298 samples: 52 from the Latrobe-1 borehole and 246 from the Point Margaret outcrop section. For these analyses, approximately $0.3 \mathrm{~g}$ of freeze-dried sediment was homogenized and decalcified using two $1 \mathrm{M} \mathrm{HCl}$ steps. Residues were neutralized using deionized water and dried in a stove at $40^{\circ} \mathrm{C}$. Subsequently, samples were homogenized again and measured for total organic carbon and nitrogen on a Fisons 1500 CNS elemental analyzer at Utrecht University and carbon isotopes on a ThermoScientific DeltaV Advantage coupled to a ThermoScientific Flash 2000 elemental analyzer at the Royal Netherlands Institute for Sea Research (NIOZ).

\subsubsection{Palynology}

A total of 121 samples - 33 samples from the Latrobe-1 drill core and 88 samples from the Point Margaret outcrop were analyzed. Detailed determination for pollen, spores and dinocysts was performed for the Latrobe-1 and for dinocysts in the Point Margaret material. Methods followed those described in Sluijs et al. (2003) and included spiking with exotic marker spores (Lycopodium clavatum; Lund University batch no. $3862 ; n=9666$ ) to allow the calculation of absolute palynomorph abundances (i.e., specimens per gram of dry sediment). Carbonates and silicates were removed from 3 to $15 \mathrm{~g}$ of dry sediment using two steps of $30 \%$ hydrochloric $(\mathrm{HCl})$ and $38-40 \%$ cold hydrofluoric $(\mathrm{HF})$ acids. The residues were neutralized using deionized water and then sieved over 10 and $250 \mu \mathrm{m}$ nylon sieves to remove small and large particles. The $10-250 \mu \mathrm{m}$ fraction of the unoxidized residues was mounted on a microscope slide using glycerine jelly. All sample residues and slides are stored at the Laboratory of Palynology and Paleobotany, Utrecht University, Utrecht, the Netherlands. Dinocyst taxonomy generally follows Fensome and Williams (2004), except for Wetzelielloideae, where we follow Bijl et al. (2016). Pollen and spore taxonomy follows Harris (1965), Macphail et al. (1994), and Stover and Partridge (1973).

\subsubsection{Carbonate percentage measurements}

The carbonate concentration of 50 Point Margaret samples was determined at the University of Southampton using a UIC CM5015 coulometer coupled to an AutoMateFX autosampler and carbonate digestion system. Approximately $0.5 \mathrm{~g}$ of each sample was freeze-dried, crushed with an agate mortar and pestle and placed in a glass vial. Due to the low carbonate concentration of most samples, relatively large samples $(\sim 30-40 \mu \mathrm{g})$ of bulk dry sample were used for the analysis. These were weighed out on a microbalance and placed in a septum-capped autosampler vial prior to each run. A total of 50 samples was analyzed on two runs on separate days. Each run was calibrated using blank-corrected counts for a calcium carbonate standard (Acros Organics, 99.999\% pure) spanning a mass range of $2-10 \mu \mathrm{g}$. The detection limit was determined from a compilation of blank analyses from multiple runs during the analysis period, and, using the average blank counts plus $3 \times \mathrm{SD}$, the detection limit for a typical $35 \mathrm{mg}$ sample was calculated to be $0.05 \% \mathrm{CaCO}_{3}$.

\section{Results}

\subsection{Lithology}

\subsubsection{Point Margaret}

A detailed lithological description of the Point Margaret outcrop was made during the field expedition in February 2016 (Fig. 4). Lower-resolution logging efforts exist for outcrops nearby (e.g., Arditto, 1995), notably from Pebble Point and Buckley's Point to the east of the Point Margaret outcrop. Some lateral differences in lithology are expected between each of these outcrops given the highly dynamic, shallowmarine depositional environment (Keating, 1993; Holdgate and Gallagher, 2003). We determined the positions of the different members composing the Pebble Point Formation at Point Margaret as they were described from other outcrops by Keating (1993) and Holdgate and Gallagher (2003) (Fig. 1c, Fig. 4). The unconformity between the early Cretaceous chloritic volcanogenic sandstones of the Otway Group and the coarse arenaceous sandstones of the lowermost Pebble Point Formation is situated at a stratigraphic height of $1.7 \mathrm{~m}$ above the base of the outcrop. 
The unconformity marking the boundary between the Margaret Member and the Buckley Member is at the top of $\mathrm{a} \sim 1.5 \mathrm{~m}$ thick black silty mudstone at a stratigraphic level of $10.7 \mathrm{~m}$. Typically, mudstones in the lower part of the Pebble Point Formation are rare and thin $(<0.5 \mathrm{~m})$, allowing this unit to be readily identified in the field. The transition from the Buckley Member to the Cobble Cove Member is not as clear and placed here at the base of a coarsening upwards sequence below a thick sandstone $(18.9 \mathrm{~m})$. The conformable transition from the Cobble Cove Member to the Pember Mudstone is around $23 \mathrm{~m}$, where a sandstone-dominated lithology is replaced by muddy sandstone and subsequently silty mudstone. Near the top of the outcrop, at $\sim 50.8$ section meters, a marked color and lithology change from organicrich black-brown silty mudstone to less organic-rich grey clay occurs.

The Buckley and Cobble Cove members contain some calcareous macrofossils that are mostly concentrated in two beds (around 15 and $18 \mathrm{~m}$ ) in the Buckley Member. The Margaret Member and Pember Mudstone are mostly devoid of carbonates. Calcium carbonate percentages were always below detection in the upper part of the Pember Mudstone, except for one of the concretionary horizons at $\sim 37.5 \mathrm{~m}$, where minor amounts $(<0.7 \%)$ of $\mathrm{CaCO}_{3}$ were found. Except for some homogeneous sandstone units of the Buckley Member, bioturbation in the form of millimeter- to centimeter-scale ophiomorphic burrows is observed in most units.

\subsubsection{Latrobe-1}

The identification of the different members within the Dilwyn and Pebble Point Formation is more challenging in the Latrobe-1 borehole (Fig. 5). Our lithological description is based on the initial wire line logging interpretation of Esplan (1971) supplemented by observations of Eglington (2006) and our own observations during discrete sampling. The Pebble Point Formation comprises sandstones, minor shales and carbonate cemented units recorded between borehole depths 344.4 and $396.2 \mathrm{~m}$. Based on wire line log data, it may be extended to $432.8 \mathrm{~m}$ where it conformably overlies Upper Cretaceous sandstones and shales of the Sherbrook Group. In turn, the Sherbrook Group unconformably overlies the Otway Group below $603.7 \mathrm{~m}$.

Conformably overlying the Pebble Point Formation, the Pember Mudstone is present in cores between 305.4 and $344.4 \mathrm{~m}$, where it is predominantly brown silty mudstone, which is variably burrowed, carbonaceous, micaceous, glauconitic and pyritic. The Rivernook Member is the shelly sandy siltstone from 289.5 to $305.4 \mathrm{~m}$. Above the Rivernook Member the formation becomes one of alternating sandstones and mudstones with similar lithologies to the Rivernook and Pember Mudstone up to borehole depth $207.2 \mathrm{~m}$. Although the interval was designated as undifferentiated Dilwyn Formation by Esplan (1971), it may be interpreted as a continuation to the Pember Mudstone containing several silty sand interbeds. From 207.2 to $70.1 \mathrm{~m}$ borehole depth, the wire line logs and core data show predominantly sandstones with minor mudstones more typical of the Princetown Member of the Dilwyn Formation. At $70.1 \mathrm{~m}$, there is a sharp disconformity overlain by the Narrawaturk Marl (Esplan, 1971).

\subsection{Organic geochemistry}

Fine-grained lithologies throughout the Point Margaret outcrop and Latrobe-1 borehole are relatively rich in organic matter, with average TOC percentages of $1.0 \pm 0.4$ and $1.5 \pm$ $0.6 \%$, respectively. High $\mathrm{C}: \mathrm{N}$ ratios (average: $\sim 25$ ) indicate that most of the organic matter is of terrestrial origin (Hedges et al., 1997) throughout both successions.

\subsubsection{Point Margaret}

At Point Margaret, the sediments of the Pebble Point Formation are also typified by relatively high (average $-24.5 \%$ ) $\delta^{13} \mathrm{C}_{\mathrm{TOC}}$ values, which is consistent with a large terrestrial contribution (Freeman and Hayes, 1992; Sluijs and Dickens, 2012). After a gradual decrease to values around $-26 \%$ in the Pember Mudstone, a $0.5 \%$ onegative step is observed around $46 \mathrm{~m}$ across a concretionary horizon. Above this horizon, values decrease gradually to $-27 \%$ at $50.8 \mathrm{~m}$. At the top of the Pember Mudstone (50.8-51.2 m), a $~ 3 \%$ negative CIE is found, accompanied by a marked decrease in TOC and $\mathrm{C}: \mathrm{N}$ ratios. Although $\mathrm{C}: \mathrm{N}$ ratios generally decrease slightly across the onset of the CIE, terrestrial organic material remains dominant, and there is no strong correlation $\left(r^{2} \sim 0.15\right.$ ) between $\mathrm{C}: \mathrm{N}$ values and $\delta^{13} \mathrm{C}_{\mathrm{TOC}}$ in this interval (above $49 \mathrm{~m}$ ). Combined with the magnitude of the CIE, this implies that it cannot have been caused by changes in marine versus terrestrial carbon sourcing (Sluijs and Dickens, 2012). Relatively stable $\delta^{13} \mathrm{C}_{\mathrm{TOC}}$ values around $-29.6 \%$ are found from $51.2 \mathrm{~m}$ to the top of the outcrop at $52.3 \mathrm{~m}$.

\subsubsection{Latrobe-1}

In the Pember Mudstone of the Latrobe-1 borehole, the patterns are very similar to those from Point Margaret. High terrestrial input dominates the $\mathrm{C}: \mathrm{N}$ ratio and $\delta^{13} \mathrm{C}_{\mathrm{TOC}}$ signal. From 310 to $305 \mathrm{~m}$ b.s., there is a minor, gradual, negative carbon isotope shift $(\sim 1 \%$ ) ; it reaches values around $-27 \%$ o. $\delta^{13} \mathrm{C}_{\text {TOC }}$ values $(-29.4 \%$ o $)$ equivalent to those at the top of the Point Margaret outcrop are only present in one sample from an uncertain depth between $\sim 305$ and $299 \mathrm{~m}$ b.s. Core recovery in the Latrobe- 1 across this interval is very low, and the exact shape of the CIE remains therefore uncertain. The recovery of the CIE is recorded from $\sim 298.8$ to $\sim 293.3 \mathrm{~m}$ b.s., and typical earliest Eocene $\delta^{13} \mathrm{C}_{\text {TOC }}$ values $(-27 \%$ o $)$ are present from $\sim 293.3$ to $\sim 282.0$ m b.s., $\sim 0.5-$ $1 \%$ below the late Paleocene average. 


\subsection{Palynology}

\subsubsection{Point Margaret}

In the Point Margaret samples, palynological residues are continuously dominated by terrestrial material (average $>90 \%$ ). Pollen, spores and plant remains are very abundant throughout the section, but we choose to focus on the dinocyst assemblages here. Dinocysts are common in all samples studied and are particularly abundant in the intervals around 18, 34, 35.75 and $46 \mathrm{~m}$. A gradual increase in the percentages of dinocysts relative to those of terrestrial palynomorphs is observed from the start of the CIE (i.e., at $50.8 \mathrm{~m}$ ) onwards.

Stratigraphically important late Paleocene dinocyst taxa include amongst others Senegalinium dilwynense, Tanyosphaeridium xanthiopyxides, Eisenackia reticulata (Plate 3E-F), Apectodinium hyperacanthum (Plate 2C), Muratodinium fimbriatum (Plate 4J) and Florentinia reichartii (Plate 3J). Abundance events (i.e. species increases to $>30 \%$ of the assemblage) are found for Diphyes colligerum (35.5-44.5 m), Apectodinium (32.5, 46 and above $51 \mathrm{~m})$, Muratodinium $(46.07 \mathrm{~m})$ and the Areoligera group $(45.75 \mathrm{~m})$. A notable acme ( $\sim 18-22 \mathrm{~m})$ of a yet undescribed goniodomacean species (subfamily Pyrodinioideae) with an epicystal archeopyle (hereafter referred to as ?Eocladopyxis sp. 1; Plate 1A-C) is also recorded. The dinocyst Apectodinium reburrus (Partridge, 1999), an important species for the southern Australian dinocyst zonation (Partridge, $2006,1999)$ that has also been described as Spinidinium cf. S. densispinatum by Crouch (2001), is here regarded as closely related or equivalent to the now formally described taxon Vozzhennikovia tawanuiensis (Crouch et al., 2014) and hereafter referred to as $V$. cf. tawanuiensis (Plate 4L). Its occurrence is limited to few samples, and it first appears in the same sample as ?Eocladopyxis sp. 1 (at $18.12 \mathrm{~m}$ ).

\subsubsection{Latrobe-1 borehole}

Both pollen and spores and dinocyst assemblages were analyzed for the Latrobe-1 borehole. Samples are continuously dominated (although to a variable degree) by terrestrial organic material: pollen, spores and plant debris. Stratigraphically important pollen and spore taxa include Proteacidites angulatus, $P$. grandis, $P$. pachypolus (Plate 5J), P. tuberculiformis (Plate 5I), Matonisporites gigantis (Plate 5F), Myrtaceidites tenuis (Plate 5E) and Spinizonocolpites prominatus (Plate 5K). In addition, the FOs of several biostratigraphically important dinocyst species are recognized, including Apectodinium hyperacanthum, Cleistosphaeridium polypetellum, Homotryblium tasmaniense, Dracodinium rhomboideum (Plate 3A) and Rhombodinium subtile. Several abundance peaks of Senegalinium spp., Diphyes colligerum, members of the Areoligera complex (sensu Sluijs and Brinkhuis, 2009), Spiniferites spp. and Apectodinium spp. are also observed and may be used for local correla- tions. Remarkably, dinocysts seem to be much less abundant than in the Point Margaret material, possibly as a result of oxidation during long-term ( $>50$ years) core storage.

\section{Correlation with local pollen and dinocyst zonal schemes}

We correlate our dinocyst and pollen assemblages from the Latrobe-1 borehole and our dinocyst assemblages from the Point Margaret section with the regional (Gippsland Basin, South Australia) zonations of Partridge (2006, 1999). For practical purposes, we assume that stratigraphic events at the Latrobe-1 and Point Margaret sections are synchronous, as our sites are only $\sim 3 \mathrm{~km}$ apart. Dinocyst assemblages from both sections are also compared to New Zealand zonations (Crouch, 2001; Crouch et al., 2014; Wilson, 1988) and the Southern Ocean zonation of Bijl et al. (2013b) where possible. Note that the reported stratigraphic position in the Latrobe- 1 borehole is given in meters below surface ( $\mathrm{m}$ b.s.) and the stratigraphic position in the Point Margaret outcrop as stratigraphic height above the base of the outcrop (m).

\subsection{Dinocysts}

Eisenackia crassitabulata zone of Partridge (1999) (not recorded in Latrobe-1 borehole; 1.7-6.01 $\mathrm{m}$ at Point Margaret)

A few specimens of Eisenackia sp. are present in one sample $(5.38 \mathrm{~m})$ close to the base of the Pebble Point Formation at Point Margaret, and we therefore assign the base of the section to this zone. A single Trithyrodinium evittii and Isabelidinium bakeri are recorded from the lowermost sample at the base of the Pebble Point Formation $(1.7 \mathrm{~m})$. Partridge (1999) noted that these species, while characteristic of early and middle Paleocene, occur sparsely in the Eisenackia crassitabulata zone. The assemblages are consistent with the Palaeocystodinium golzowense zone of Wilson (1988) and the NZDP7 (New Zealand Dinocyst Paleocene) zone of Crouch et al. (2014).

Senegalinium dilwynense zone of Partridge (1999) (from below $369 \mathrm{~m}$ to $346.48 \mathrm{~m}$ b.s. in Latrobe-1 borehole; $6.01-13.68 \mathrm{~m}$ at Point Margaret)

The base of this zone is defined by the last occurrence (LO) of Eisenackia crassitabulata, and its top is marked by the first abundant occurrence of Vozzhennikovia cf. tawanuiensis. Samples from this zone typically contain abundant Senegalinium dilwynense. Partridge (1999) records the first occurrence (FO) of Diphyes colligerum as an accessory event within the overlying Apectodinium reburrus zone. As $V$. cf. tawanuiensis is never abundant in our samples (FO at $\sim 18.12 \mathrm{~m}$ ), we use the FO of Diphyes colligerum $(15.28 \mathrm{~m}$ at Point Margaret; 341.13 m b.s. in the Latrobe-1 borehole) 

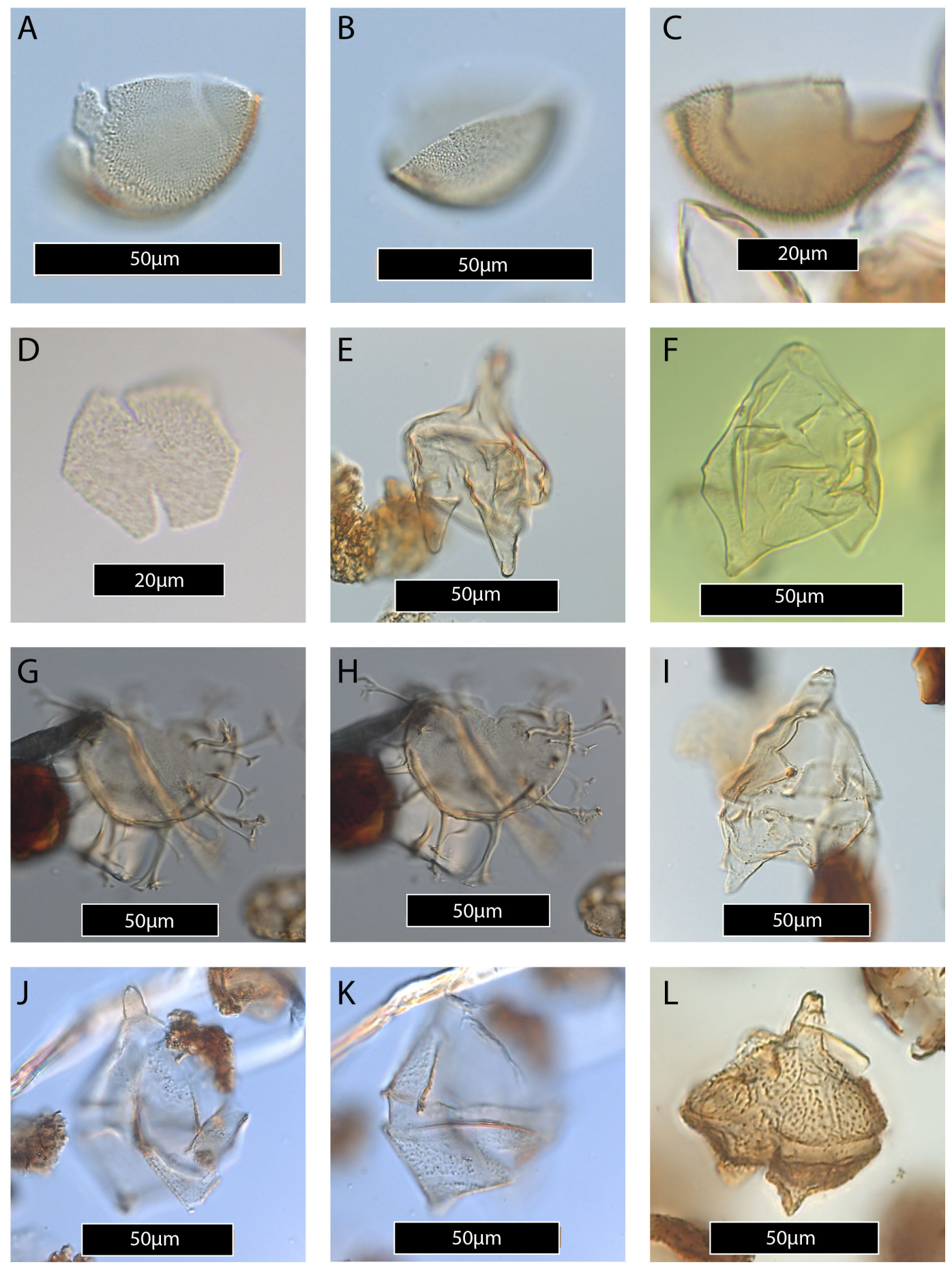

Plate 1. (A) ?Eocladopyxis sp. 1, specimen showing sulcal area semidetached. (B) ?Eocladopyxis sp. 1 (same specimen as A), focus of the paratabulation indicators on the cingular plates. (C) ?Eocladopyxis sp. 1, specimen possessing a rather thick layer of hair-like ornamentation compared to more granulate ?Eocladopyxis sp. 1 as pictured in (A-B). (D) Apical plates $\left(1^{\prime}-3^{\prime}\right)$ of ?Eocladopyxis sp. 1, this cluster of apical plates often remains intact during archeopyle formation in Goniodomoideae and is abundant found in samples with ?Eocladopyxis sp. 1. (E) Morkallacysta sp.?, specimen with pronounced apical and antapical horns. (F) Morkallacysta pyramidalis. (G-H) Glaphyrocysta sp., specimen with processes typical of Enneadocysta. (I) Deflandrea pachyceros (Cookson and Eisenack, 1965). Note the iso- to stenodeltaform $2 \mathrm{a}$ archeopyle and the tabular ornamentation. (J-K) Ginginodinium tabulatum (same specimen, high and low focus) (Cookson and Eisenack, 1965). (L) Ginginodinium paleocenicum (Cookson and Eisenack, 1965). 

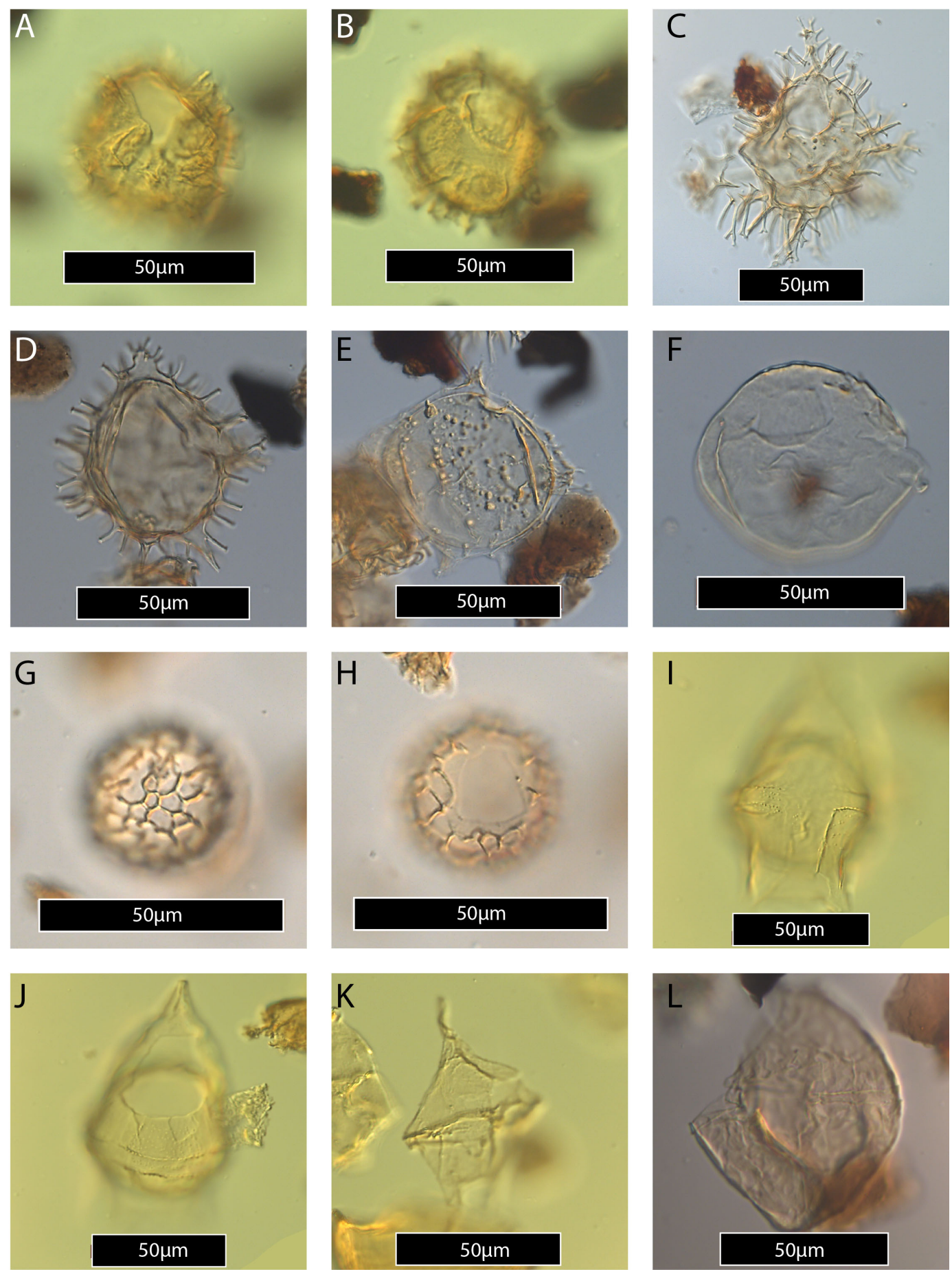

Plate 2. (A-B) Achilleodinium biformoides (same specimen, high and low focus). (C) Apectodinium hyperacanthum. (D) Apectodinium quinquelatum. (E) Apectodinium quinquelatum specimen with strongly reduced processes and peri- and endophragm separated. (F) Apectodinium? - endophragm only. (G-H) Cerebrocysta bartonensis (same specimen, high and low focus). (I-J) Cerodinium dartmoorium (same specimen, high and low focus). (K) Cerodinium depressum. (L) Cribroperidinium guiseppii.

to constrain the highest possible stratigraphic position of the Senegalinium dilwynense zone and the base of the overlying Apectodinium reburrus zone of Partridge (1999). The zone is equivalent to the lower part of the NZDP8 zone of Crouch et al. (2014) and lies entirely within the $P$. golzowense zone of Wilson (1988). 

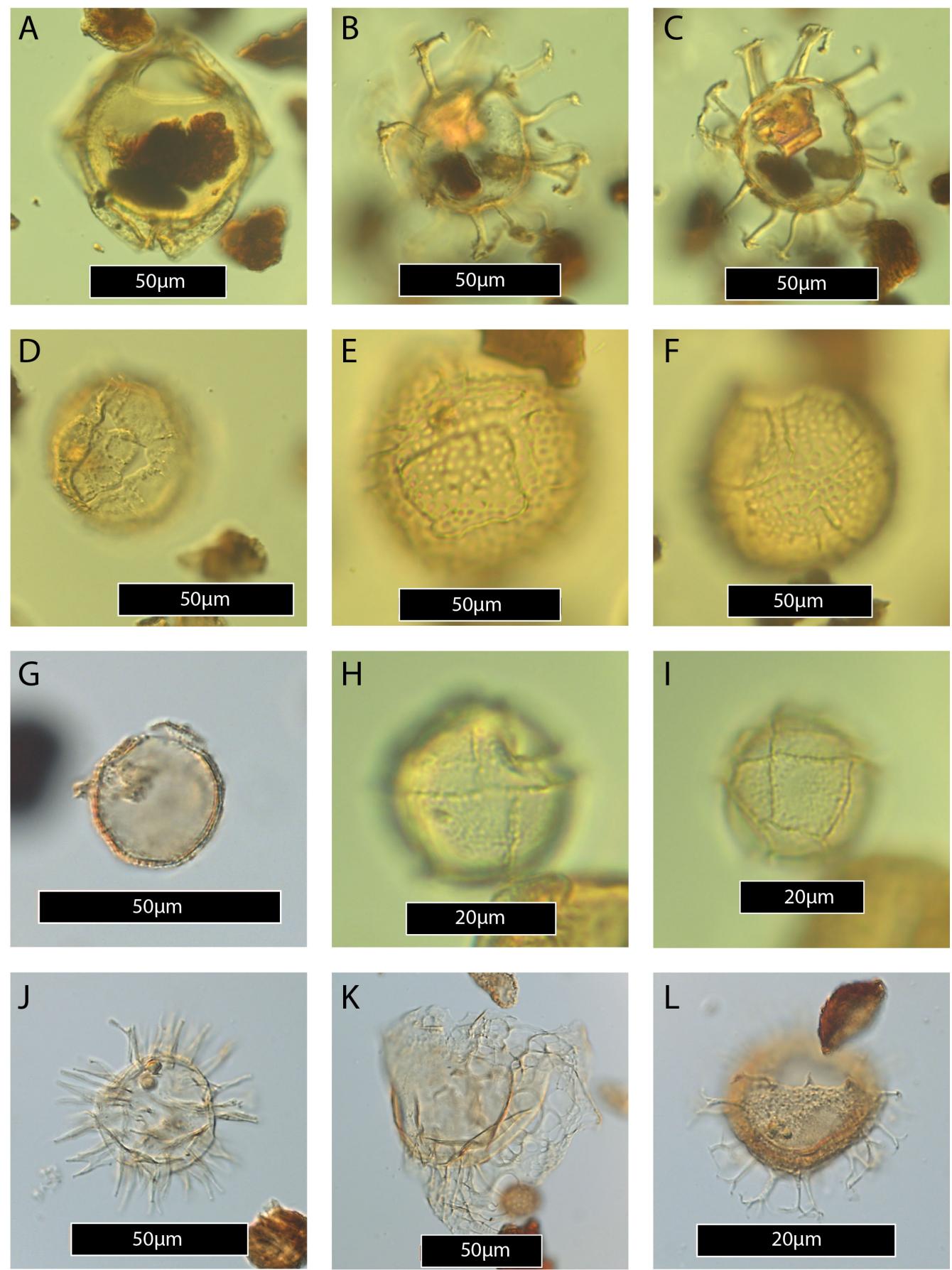

Plate 3. (A) Dracodinium rhomboideum. (B-C) Enneadocysta dictyostila (same specimen, high and low focus). (D) Eisenackia margarita group. (E-F) Eisenackia reticulata (same specimen, high and low focus). (G) Elytrocysta sp. (H-I) Fibradinium annetorpense (same specimen, high and low focus). (J) Florentinia reichartii. (K) Glaphyrocysta pastielsii. (L) Hafniasphaera septata.

Apectodinium reburrus zone of Partridge (1999), hereafter $V$. cf. tawanuiensis zone $(346.48-308.69 \mathrm{~m}$ in Latrobe-1 borehole, $13.68-32.5 \mathrm{~m}$ at Point Margaret)

In this study, we use the FO of Diphyes colligerum as a proxy to constrain the base of this zone (see above) and the top is defined as the FO of Apectodinium hyperacanthum. Important bio-events within this zone include the FO of $V$. cf. tawanuiensis, in samples that are dominated by ?Eocladopyxis sp. 1. The FO of the genus Apectodinium (represented by A. homomorphum) is within the lower part of the zone $(341.13 \mathrm{mb}$.s. in the Latrobe- 1 borehole and 

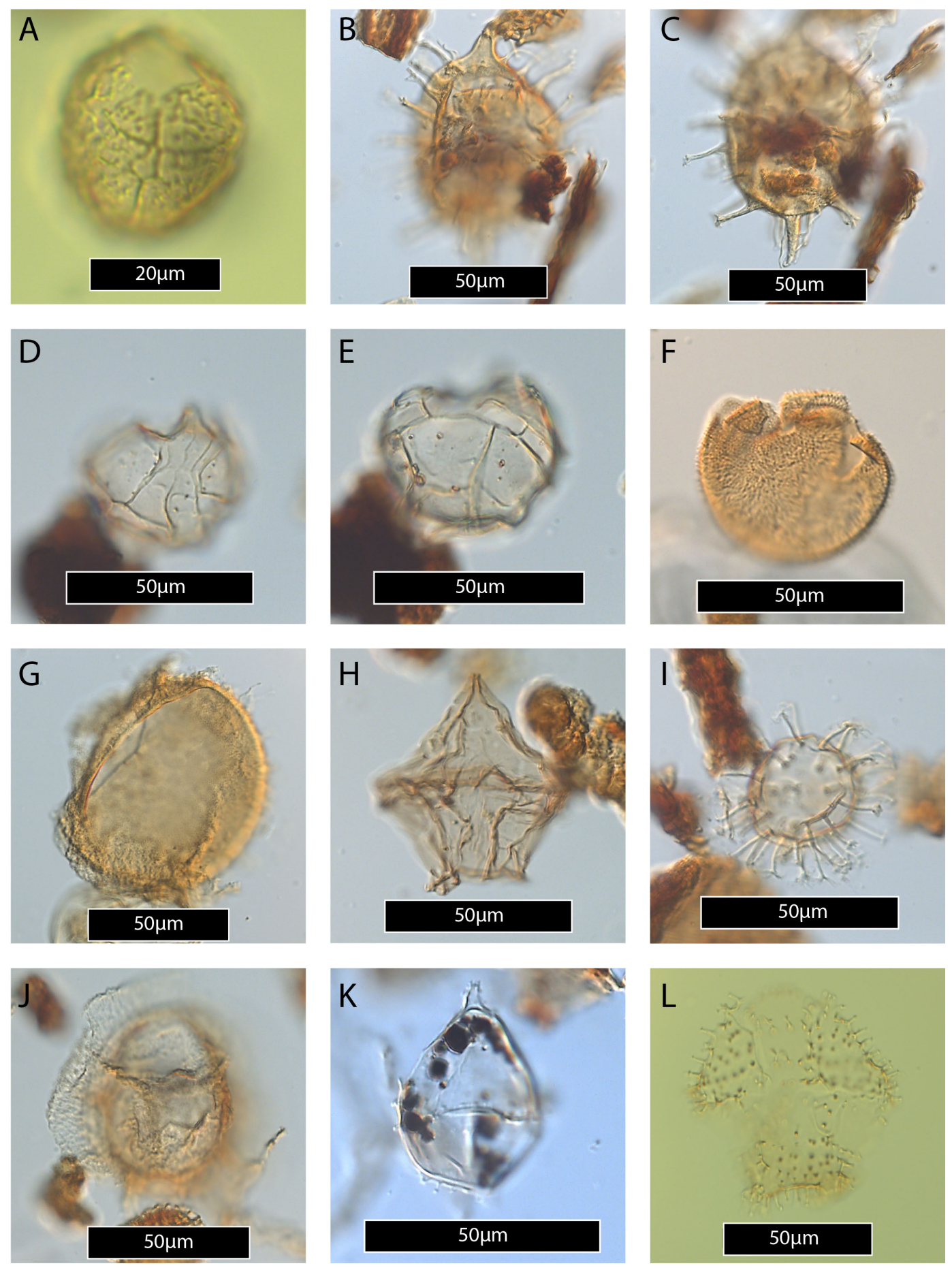

Plate 4. (A) Histiocysta palla? (B-C) Ifecysta lappacea. (D-E) Impagidinium aculeatum. (F) Kallosphaeridium brevibarbatum. (G) Lanternosphaeridium lanosum. (H) Lejeunecysta hyalina. (I) Melitasphaeridium pseudorecurvatum. (J) Muratodinium fimbriatum. (K) Spinidinium sp.? (L) Vozzhennikovia cf. tawanuiensis.

$19.88 \mathrm{~m}$ at Point Margaret). This bio-event is noteworthy as the genus Apectodinium has an FO around the DanianSelandian boundary in the Tethys (Guasti et al., 2005) but typically appears only slightly before or at the onset of the
PETM at higher latitudes (Crouch et al., 2014, 2001; Sluijs et al., 2007). The $V$. cf. tawanuiensis zone falls completely within the NZDP8 zone of Crouch et al. (2014) and the P. golzowense zone of Wilson (1988). 

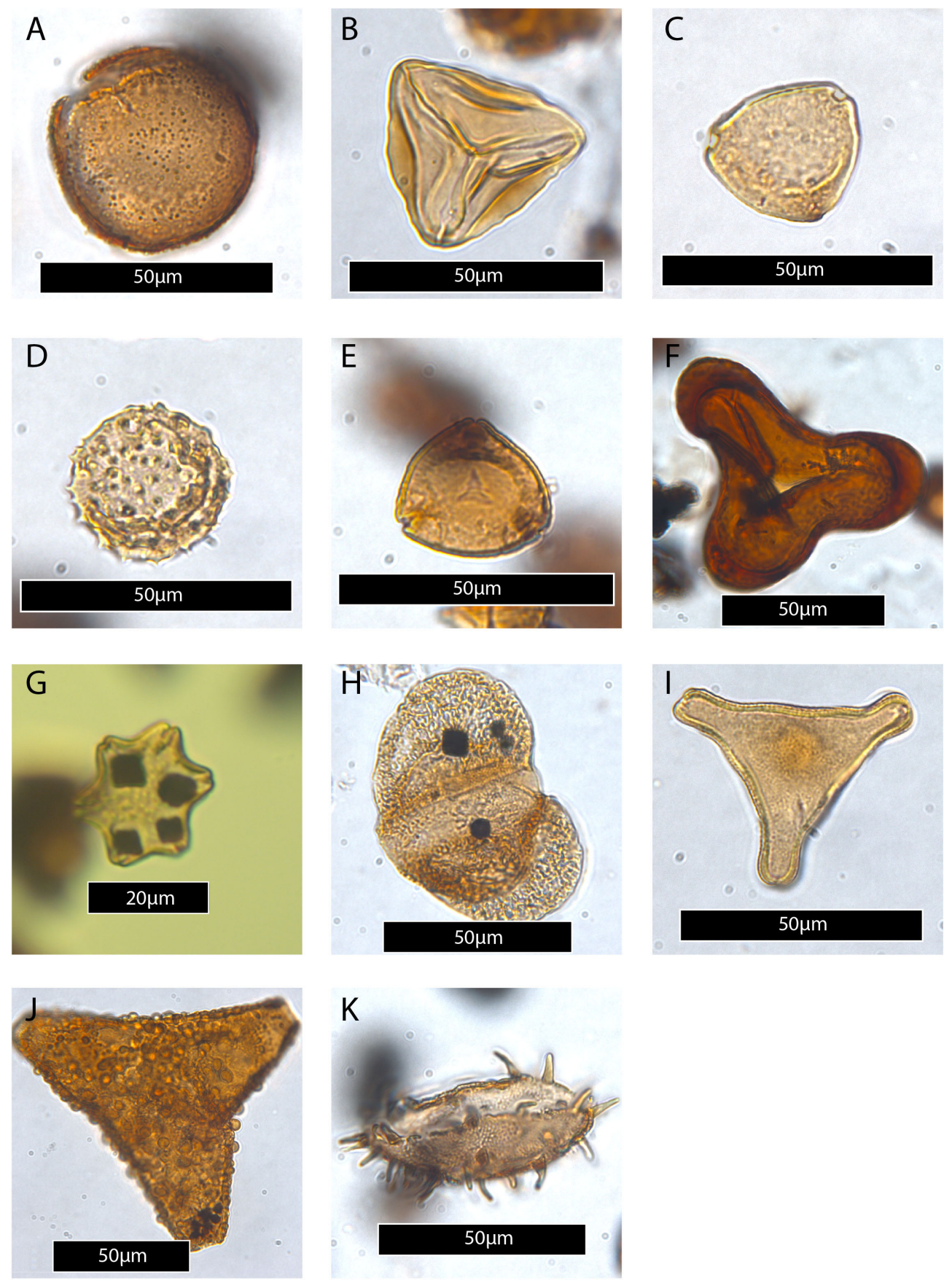

Plate 5. (A) Dilwynites granulatus. (B) Gleicheniidites senonicus. (C) Haloragacidites harrisii. (D) Malvacipollis subtilis. (E) Myrtaceidites tenuis. (F) Matonisporites gigantis. (G) Nothofagidites falcatus. (H) Podocarpidites ellipticus. (I) Proteacidites pachypolus. (J) Proteacidites tuberculiformis. (K) Spinizonocolpites prominatus.

Apectodinium hyperacanthum zone of Partridge (1999) (308.69-292.56 $\mathrm{m}$ in Latrobe-1 borehole, from $32.5 \mathrm{~m}$ onwards (top not recorded) at Point Margaret)

The A. hyperacanthum zone is based on the regional range of A. hyperacanthum. Because of low dinocyst counts in the Latrobe-1 borehole and relatively low sample resolution, we may have missed the true FO of A. hyperacanthum. In both our successions, the base of this zone is also marked by a short-lived abundance of Apectodinium spp. The 3\% CIE, which we interpret to represent the PETM (see Sect. 4.3), falls within this zone, although the exact position within the zone remains uncertain as the top of the zone is not recorded at Point Margaret and the base of the zone is poorly 
constrained in the Latrobe-1. Remarkably, there are several Apectodinium acme ( $>40 \%$ of assemblage) events; however, only one is associated with the PETM CIE. Florentinia reichartii is present only during the CIE and the species may hence serve as an additional dinocyst marker species for the PETM in the Otway Basin.

At Point Margaret, the lowermost Apectodinium acme $(\sim 46 \mathrm{~m})$ is associated with a minor $(0.5-1 \%$ ) negative shift in $\delta^{13} \mathrm{C}_{\mathrm{TOC}}$ and a concretionary horizon (Fig. 4). Higher relative abundance of marine organic matter within the concretionary horizon suggests that this minor CIE may partly result from decreased terrigenous sediment supply. Although a similar step in $\delta^{13} \mathrm{C}_{\mathrm{TOC}}$ is not recorded in the Latrobe1 , we record a $\sim 1 \%$ o gradual $\delta^{13} \mathrm{C}_{\mathrm{TOC}}$ negative shift from 310.2 to $305.2 \mathrm{~m}$ b.s. coincident with elevated Apectodinium abundances. This may imply the interval is not condensed at Latrobe-1 as it is at Point Margaret. Importantly, the observed contemporaneous Apectodinium acme and small CIE predate the main PETM CIE and illustrate the importance of using additional stratigraphic markers to identify the PETM CIE in the Otway Basin.

The FO of A. hyperacanthum at Point Margaret is associated with the first common occurrence (FCO) of Apectodinium homomorphum, and the base of the A. hyperacanthum zone is therefore equivalent to the base of the SPDZ1 zone of Bijl et al. (2013b) and the NZE1 zone of Crouch (2001) but not the A. homomorphum zone of Wilson (1988). This is the result of slightly different definitions; Bijl et al. (2013b) and Crouch (2001) based their zones on the FCO of A. homomorphum and FCO of the genus Apectodinium respectively, whereas the A. homomorphum zone of Wilson (1988) is based on the $\mathrm{FO}$ of $A$. homomorphum.

\section{Apectodinium homomorphum zone of Partridge (1999)} (292.56-109.26 m in Latrobe-1 borehole, not recorded at Point Margaret)

The A. homomorphum zone spans from the LO of A. hyperacanthum to the FO of Homotryblium tasmaniense. Given that the FO of $H$. tasmaniense in the AAG (IODP Site $\mathrm{U} 1356)$ is placed close to the base of C23n.2n ( 51.8 Ma; Bijl et al., 2013b), this zone is particularly long ( $\sim 4 \mathrm{Myr})$, and several important bio-events are found within this zone that may warrant a subzonation. The typical marker species (e.g., Samlandia delicata, Impagidinium cassiculum, Dracodinium waipawaense) for the New Zealand and East Tasman Plateau zonations of Crouch (2001), Crouch and Brinkhuis (2005), and Wilson (1988) are not recognized in the early Eocene of the Latrobe- 1 borehole. There are a few specimens of Rhombodinium subtile at 229.8 and $208.1 \mathrm{mb}$.s. and the FO of Cleistosphaeridium polypetellum at $140.8 \mathrm{mb}$ b.s., which can be used for correlation with IODP Site U1356. Macrofossil-bearing Trochocyathus ( $255 \mathrm{mb}$ b.s.) and Turritella ( $\sim 265 \mathrm{mb}$ b.s.) beds are located in the lower part of the A. homomorphum zone (Eglington, 2006). Based on the
FO and LO of Rhombodinium subtile we place the SPDZ3-4 zone of Bijl et al. (2013b) and the NZE2a-2b zone of Crouch (2001) within the Apectodinium homomorphum zone. The FO of Cleistosphaeridum polypetellum is confined to the SPDZ4 zone of Bijl et al. (2013b), and this bio-event is identified in the upper part of the Apectodinium homomorphum zone of Partridge (1999).

Homotryblium tasmaniense zone of Partridge (1999) (109.26-77.45 m b.s. in Latrobe-1 borehole, not recorded at Point Margaret)

The only occurrence of $H$. tasmaniense at $96.34 \mathrm{~m}$ b.s. in the Latrobe-1 borehole marks the presence of this zone. Due to large sampling gaps, the base of the zone is poorly constrained but must be located in the interval between 140.8 and $96.34 \mathrm{~m}$ b.s. The top, defined by the LO of $H$. tasmaniense, is between 96.34 and $67.35 \mathrm{mb}$ b. The co-occurrence of $\mathrm{H}$. tasmaniense and $C$. polypetellum indicates that this zone is likely equivalent to the SPDZ5(-6) zone of Bijl et al. (2013b), the NZE4 zone of Crouch (2001) and the Wilsonidium ornatum zone of Wilson (1988).

Deflandrea heterophlycta zone of Partridge (1999)

(67.35 m b.s. in Latrobe-1 borehole, not recorded at Point Margaret)

Achilleodinium biformoides is rare in the southern Australian basins but recorded here in the topmost sample we analyzed for the Latrobe-1 borehole. While the species is long ranging, it only appears at IODP U1356 around or just after $\sim 40 \mathrm{Ma}$ (SPDZ 13 of Bijl et al., 2013b). Following Partridge (1999) the presence of $A$. biformoides indicates the presence of the Deflandrea heterophlycta zone. More importantly, specimens attributable to Dracodinium rhomboideum are also present; this species marks the base of SPDZ13 of Bijl et al. (2013b) and is restricted to C18n.2n (40.14-39.7 Ma). These sediments may hence be interpreted to represent the Middle Eocene Climate Optimum (MECO; 40 Ma).

\subsection{Latrobe-1 pollen and spores}

Proteocidites angulatus subzone of Partridge (1999); base not recorded $-360.43 \mathrm{~m}$ b.s. (upper

Lygistepollenites balmei zone of Partridge, 1999)

The base of the Proteocidites angulatus subzone is determined by the range of the eponymous species. P. angulatus is here recorded only in the lowermost sample. Potential accessory dinocyst bio-events include the LO of Eisenackia (not present) and the FO of Hafniasphaera septata (present from the base of the section). Pollen assemblages in this subzone are accompanied by abundant Senegalinium dilwynense. 
Propyllipollis annularis subzone of Partridge (1999) (360.43-312.4 m b.s.) (upper Lygistepollenites balmei zone of Partridge, 1999)

The base of this subzone is marked by the top of the previous zone, and the top is based on the FO of Matonisporites gigantis. Pollen assemblages contain consistent Propyllipollis annularis (a few \%) and are dominated (>50\%) by Dilwynites spp. This subzone is approximately time-equivalent to the Apectodinium reburrus (here $V$. cf. tawanuiensis) dinocyst zone of Partridge (1999).

Matonisporites gigantis subzone of Partridge (1999) (312.4- $303 \mathrm{~m}$ b.s.) (upper Lygistepollenites balmei zone of Partridge, 1999)

The FO of Matonisporites gigantis (310.72 m b.s.) marks the base of this subzone, and the FO of Spinizonocolpites prominatus (between 305.19 and $299.67 \mathrm{~m}$ b.s.) marks the top. Partridge (2006) notes the FO of Matonisporites gigantis as slightly preceding the FO of A. hyperacanthum. Both bioevents are recorded in the same sample here. A minor, seemingly gradual negative shift in $\delta^{13} \mathrm{C}_{\mathrm{TOC}}$ is observed from $\sim 310.2$ to $\sim 305.2 \mathrm{mb}$.s. and is regarded as being equivalent to a condensed interval around $46 \mathrm{~m}$ at Point Margaret. The subzone directly precedes the larger $(\sim 2.5 \%$ o $)$ negative shift in $\delta^{13} \mathrm{C}_{\mathrm{TOC}}$ marking the PETM.

\section{Spinizonocolpites prominatus subzone of Partridge} (1999) ( 303-292.56 m b.s.) (Malvacipollis diversus zone of Partridge, 1999)

This subzone is based on the FO of the eponymous pollen species, here recorded between 305.2 and $299.64 \mathrm{~m}$ b.s. The exact position of the sample placed between 305.2 and $299.64 \mathrm{mb}$.s. and hence the onset of the CIE can only be poorly constrained but must be located between 305.2 and $299.64 \mathrm{~m}$ b.s. Spinizonocolpites prominatus is notably associated with the most negative $\delta^{13} \mathrm{C}_{\mathrm{TOC}}$ values, and the $\mathrm{FO}$ here coincides with the large CIE that marks the PETM. The FO of Intratriporopollenites notabilis ( $299.64 \mathrm{~m}$ b.s.) is recorded at the base of this subzone.

Proteacidites grandis subzone of Partridge (1999) (292.56-244.78 m b.s.) (Malvacipollis diversus zone of Partridge, 1999)

The base of the $P$. grandis subzone is marked by the last common occurrence (LCO)s of L. balmei. However, Lygistepollenites is not abundant in the Latrobe-1, and we did not record any specimens clearly attributable to L. balmei. This implies we were not able to determine the LCO of this species in the Latrobe-1. We therefore use the timeequivalent LO of A. hyperacanthum (Partridge, 1999) to approximate the position of the base of the subzone. The top of the zone is marked by the FO of Proteacidites tuberculiformis $(229.8 \mathrm{mb}$ b.s.). The base of the subzone is approximately time-equivalent to the base of the Apectodinium homomorphum zone. Consequently, the fossiliferous Trochocyathus ( $\sim 265 \mathrm{~m}$ b.s. $)$ and Turritella $(\sim 255 \mathrm{~m}$ b.s.) beds are located in the middle part of the $P$. grandis subzone (Eglington, 2006).

Proteacidites tuberculiformis subzone of Partridge (1999) (244.78- 187.83 m b.s.) (Malvacipollis diversus zone)

The base and top of this subzone are marked by the FO of $P$. tuberculiformis (229.8 m b.s.) and FO of Myrtaceidites tenuis (167.64 m b.s.), respectively. Notable accessory bioevents within this subzone include the FO and LO of Rhombodinium subtile. The pollen species Haloragacidites harrisii has a first common occurrence (> 5\%) in this zone.

Myrtaceidites tenuis subzone of Partridge (1999) ( 187.83- 87 m b.s.) (Malvacipollis diversus zone)

The FO of Myrtaceidites tenuis (Plate 5F) marks the base of this subzone. The top of the subzone (FO of Santalumidites cainozoicus) is not recorded in our Latrobe-1 sample set but was located at $\sim 87 \mathrm{~m}$ b.s. by Archer (1977). Accessory bioevents include the FO of several stratigraphically important dinocyst taxa, notably Cleistosphaeridium polypettelum at $140.8 \mathrm{~m}$ b.s. and Homotryblium tasmaniense at $96.34 \mathrm{~m}$ b.s. Pollen assemblages are characterized by abundant to dominant $H$. harrisii.

Santalumidites cainozoicus subzone of Partridge (1999) ( $87 \mathrm{~m}$ b.s.) (Malvacipollis diversus zone)

The FO of Santalumidites cainozoicus is not recorded in this work but based on its FO recorded in the original report by Archer (1977), the Santalumidites cainozoicus subzone is present in the Latrobe- 1 around $87 \mathrm{~m}$ b.s.

\section{Lower Nothofagidites asperus zone of Partridge (1999)} (67.35 m b.s.)

The Proteacidites asperopolus zone of Partridge (1999) is not recorded in the Latrobe-1 borehole, suggesting the presence of a hiatus that includes a substantial part of the early and middle Eocene. The topmost sample analyzed (at $67.35 \mathrm{mb}$ b.s.) yields abundant $(>20 \%)$ Nothofagidites spp. and notably also Nothofagidites falcatus (Plate 5G). We therefore correlate our highest analyzed sample with the middle Eocene lower Nothofagidites asperus zone of Partridge (1999). 


\subsection{Absolute age and correlation with regional and global events}

\subsubsection{Absolute age}

Key early to middle Paleocene dinocyst species used in the Paleocene dinocyst zonation of New Zealand (Crouch et al., 2014) include Palaeoperidinim pyrophorum, Deflandrea foveolata, Isabelidinium bakeri, I. cingulatum and Trithyrodinium evittii. A single specimen of T. evittii and I. bakeri are found at the base of the Pebble Point at the Point Margaret outcrop $(1.7 \mathrm{~m})$, but the absence of any other indicators (e.g. the more common $P$. pyrophorum) suggests that it is unlikely that these signal the presence or reworking of early to middle Paleocene sediments, and we therefore follow Partridge (1999) in his interpretation and assign these assemblages to the late Paleocene Eisenackia crassitabulata zone.

The lowermost beds of the Pebble Point Formation, the Margaret Member, contain a few sparse Eisenackia reticulata. Although this species ranges well across the PaleoceneEocene boundary at ODP Site 1172 on the East Tasman Plateau (ETP) (Bijl et al., 2013b), the dinocyst zonation for the New Zealand region (Crouch et al., 2014) places the LO of the genus Eisenackia at $\sim 59.0 \mathrm{Ma}$. The overlying Buckley Member and Cobble Cove Member yield sparse calcareous microfossils, notably Globanomalina australiformis; the FO of this species has been calibrated to predate the onset of the PETM CIE $(\sim 56.0 \mathrm{Ma})$ in the Atlantic and Indian sectors of the Southern Ocean by 50 to $560 \mathrm{kyr}$ (Huber and Quillévéré, 2005). This would suggest that the upper parts of the Pebble Point Formation, the Buckley and Cobble Cove members, are unlikely to be much older than $\sim 56.5 \mathrm{Ma}$. The LO of Eisenackia may be considered one of the important dinocyst events for the late Paleocene, but it is in fact strongly diachronous in the region and its range may extend into the earliest Eocene (Bijl et al., 2013b; Crouch et al., 2014). Combined with the highly dynamic, shallow marine sedimentation regime, this suggests that the base of the Point Margaret section may not be much older than indicated by the FO of G. australiformis $(\sim 56.5 \mathrm{Ma})$.

A large negative CIE of $\sim 3 \%$ ( $50.8 \mathrm{~m}$ at Point Margaret, $\sim 305-299 \mathrm{~m}$ b.s. in the Latrobe-1) is recorded within the top part of the Pember Mudstone. Notably, this CIE postdates the FO occurrence of G. australiformis (Huber and Quillévéré, 2005 ) and predates the LO of Morozovella acuta $(\sim 55.3 \mathrm{Ma})$ (Wade et al., 2011) in the Rivernook beds (McGowran, 1970, 1965). This, along with palynological bio-events discussed earlier, implies the CIE must represent the PETM ( 56 Ma). At Point Margaret, the onset and part of the peak of the PETM CIE are recovered; the recovery phase of the CIE and younger sediments are missing or not exposed.

The $\sim 36 \mathrm{~m}$ of sediment accumulation between the FO of G. australiformis and the CIE implies that most of the Point Margaret succession accumulated rapidly. If a maximum duration of $500 \mathrm{kyr}$ is assumed between the FO of G. australi- formis and the CIE, then the minimum average accumulation rate was $7.2 \mathrm{~cm} \mathrm{kyr}^{-1}$. However, accumulation rates were likely higher in some intervals, as at least one condensed interval is present $(\sim 46 \mathrm{~m})$.

In the Latrobe- 1 borehole, a minimum thickness of $7.3 \mathrm{~m}$ and maximum thickness of $14.8 \mathrm{~m}$ is inferred for the CIE, implying sediment accumulation rates between $\sim 3.6$ and $\sim 9.9 \mathrm{~cm} \mathrm{kyr}^{-1}$. We further note that the thickness of the Pember Mudstone below the CIE in the Latrobe-1 borehole $(36-41 \mathrm{~m})$ is larger than at Point Margaret, suggesting slightly higher accumulation rates $\left(>7.2 \mathrm{~cm} \mathrm{kyr}^{-1}\right)$. This inference is supported by the relative positions of secondary bio-events within the Point Margaret and Latrobe-1 successions.

In the Latrobe-1 borehole, we find Rhombodinium subtile (229.2-208.01 m b.s.), Cleistosphaeridium polypetellum (140.8 m b.s.) and Homotryblium tasmaniense (96.34 m b.s.). At IODP Site U1356, $R$. subtile is present from the base of C24n.3n ( 53.98 Ma) to C24n.1n (top at 52.62 Ma), while $H$. tasmaniense first appears at the base of $\mathrm{C} 23 \mathrm{n} .2 \mathrm{n}$ ( $\sim 51.8 \mathrm{Ma})$ (Bijl et al., 2013b). It is important to note that H. tasmaniense occurs much earlier $(\sim 53.8 \mathrm{Ma})$ on the SW Pacific side of the Tasmanian Gateway, and the FO of H. tasmaniense is assigned a much older age in the Gippland Basin (Partridge, 1999, 2006). However, when comparing this to the records from the AAG, the datum partly overlaps with existing foraminifer stratigraphy (McGowran, 1991; Taylor, 1964), which suggests a datum close to Eocene planktonic foraminifer zone E6 $(\sim 51 \mathrm{Ma})$ for the equivalent of the Princetown Member (above $\sim 255$ m b.s.) at Ceduna Plateau (McGowran, 1991). The middle Eocene sediments, above the Lutetian gap, likely belong to the Narrawaturk Marl. Although represented by only one sample at $67.35 \mathrm{mb}$ b.s., dinocyst biostratigraphy suggests that the middle Eocene sediments in the Latrobe-1 borehole are close in age to the MECO (ca. $40 \mathrm{Ma}$ ), consistent with previous interpretations (Arditto, 1995). The MECO is a $\sim 500 \mathrm{kyr}$ warming event that may be associated with sea-level rise (Sluijs et al., 2013; Witkowski et al., 2014), and in the AAG this interval is associated with the thermophilic Maslin Bay flora (McGowran and Hill, 2015) and neritic carbonates in the west (e.g., McGowran et al., 2004).

\subsubsection{Local, regional and global events}

The first occurrence of Apectodinium homomorphum at $21.03 \mathrm{~m}$ at Point Margaret within the Cobble Cove Member is noteworthy and predates the PETM by $\sim 50-500 \mathrm{kyr}$, based on correlation with planktonic foraminiferal biostratigraphy. The species Apectodinium hyperacanthum, used to define the eponymous dinocyst zone of Partridge (1999), is first found at $32.5 \mathrm{~m}$. This coincides with the first abundant Apectodinium spp., forming up to $30 \%$ of the total dinocyst assemblage. A second abundance peak of Apectodinium spp. (up to $60 \%$ ) is found at $46 \mathrm{~m}$, and a third (up to $60 \%$ ) occurs at 
the onset of the CIE (51 m). The PETM CIE in the Latrobe-1 borehole is also associated with an Apectodinium acme (up to $\sim 90 \%$ ).

Some late Paleocene to early Eocene dinocyst bio-events may be used both in the SW Pacific and AAG. This may include the FO of the (sub)tropical dinocyst genus Apectodinium in the last $\sim 500 \mathrm{kyr}$ of the Paleocene. It may seem that the appearance of Apectodinium in the AAG precedes the appearance of this genus on the ETP (Sluijs et al., 2011). However, care should be taken in using this datum as it relies on association with the FO of Globanomalina australiensis in the AAG, which is allochronous across the Tasmanian Gateway (Morgans et al., 2004) but possibly also between different sites in the Atlantic and Indian sectors of the Southern Ocean (Huber and Quillévéré, 2005). It is, however, evident that Apectodinium appears in the region already in the latest Paleocene, and the genus was occasionally abundant before the PETM on both sides of the Tasmanian Gateway. These multiple abundance events complicate their correlation with the quasi-global Apectodinium acme that marks the PETM elsewhere (Crouch et al., 2001). We therefore propose the use of additional marker species to identify the PETM in the SW Pacific and AAG. At Point Margaret and in the Latrobe-1, Florentinia reichartii is present only during the PETM, as it is at ODP Site 1172 (Sluijs et al., 2011). Similar to Apectodinium, Florentinia reichartii was a thermophilic species but likely exhibited an even higher optimum temperature; notably this species also migrated polewards during the PETM (Frieling, 2016). Florentinia reichartii has only been found in the Southern Ocean during the PETM and may therefore be used as a regional dinocyst marker species.

In the absence of these dinocyst marker species, the first consistent occurrence of the pollen species Spinizonocolpites prominatus may be used to locate the Paleocene-Eocene boundary in the AAG and on the ETP. S. prominatus, closely related to pollen of the extant mangrove palm Nypa, is important for regional correlations as its first consistent appearance seems to be contemporaneous with the PETM on both sides of the Tasmanian Gateway (Contreras et al., 2014). Nypa is a thermophilic genus and requires mean annual temperatures above $\sim 22^{\circ} \mathrm{C}$ (Utescher and Mosbrugger, 2015). However, care should be taken to use single appearances of S. prominatus, as it is also present in the early Eocene strata in the Latrobe-1 borehole (this study) and in western Tasmania (Carpenter et al., 2012), and suitable ecological and climatic conditions may have been widespread along the coasts of the AAG at that time (Contreras et al., 2013; Pross et al., 2012).

Relatively large sample gaps in the Latrobe-1 dataset imply that the FO and LO of early Eocene dinocysts cannot be directly tied to those recorded at Site U1356. However, it should be noted that none of the recorded events are out of stratigraphic order and therefore may be considered consistent with the zonation established for the Southern Ocean (Bijl et al., 2013b). By extension, these events may be em- ployed for approximate age determinations until new, highresolution stratigraphic constraints become available for the lower Eocene of the Otway Basin.

\section{Conclusions}

Two expanded sedimentary successions, the Latrobe-1 borehole and the Point Margaret outcrop, in the Otway Basin of southeast Australia were studied for pollen and dinocyst biostratigraphy as well as bulk organic matter carbon isotope chemo-stratigraphy. The combination of these techniques allows us to identify the Paleocene-Eocene boundary in both successions and to create a stratigraphic framework for the latest Paleocene and early Eocene at the respective localities.

Based on previous calcareous microfossil evidence (McGowran, 1970, 1965), the Buckley Member within the Pebble Point Formation predates the Paleocene-Eocene boundary by a maximum of $\sim 500 \mathrm{kyr}$, and a lack of abundant early and middle Paleocene dinocyst taxa below indicates that the base of the Pebble Point Formation at Point Margaret may not be much older. The Paleocene-Eocene boundary is located within the top part of the Pember Mudstone and is marked by a large negative CIE $(\sim 3 \%)$ in $\delta^{13} \mathrm{C}_{\mathrm{TOC}}$. Only the onset of the CIE is recorded at Point Margaret. In the Latrobe- 1 borehole, the peak and recovery of the CIE are preserved and imply a total thickness of 7.3-14.8 $\mathrm{m}$ for the entire CIE at that site.

The first occurrence and first acme of Apectodinium predate the $\sim 3 \%$ o negative carbon isotope excursion by $\sim 50$ $500 \mathrm{kyr}$. This signal, which is very similar to that on the East Tasman Plateau (ODP Site 1172), implies that the first Apectodinium acme in this region cannot be confidently correlated with the PETM. We propose the use of additional palynological marker taxa, i.e., the presence of the dinocyst Florentinia reichartii and/or the FCO of the pollen Spinizonocolpites prominatus, to identify the Paleocene-Eocene boundary.

The presence of early Eocene sediments in the Latrobe- 1 borehole is established with the FO and LO of Rhombodinium subtile as well as with the FOs of Cleistosphaeridium polypetellum and Homotryblium tasmaniense. These species are also recorded in the early Eocene at IODP Site U1356 on the southern edge of the AAG and on the ETP (ODP Site 1172). A substantial portion of the early and middle Eocene $(\sim 51-40 \mathrm{Ma})$ is marked by nondeposition or erosion before sedimentation resumed around $40 \mathrm{Ma}$ based on the presence of the Deflandrea heterophlycta/lower Nothofagidites asperus zone and the presence of Dracodinium rhomboideum, a marker species for the MECO in the Southern Ocean.

Our results indicate the presence of late Paleocene, PETM, early Eocene and also MECO sediments in the Otway Basin, southeast Australia. Combined with the excellent spatial coverage of seismic and wire line log data for the Otway Basin, it is now possible to readily identify these critical climate 
intervals in existing boreholes and outcrops. We anticipate that forthcoming records from these sediments will play an important role in resolving the long-standing climate-model proxy-data discrepancy around the Tasmanian Gateway.

Data availability. Data used in this paper will be available in the online database Pangaea (https://doi.org/10.1594/PANGAEA.886006) (Frieling et al., 2018).

Author contributions. PKB designed the research. GH, JF, JP, PKB, SG and SMB collected the samples. CCMR EPH, THD and JF generated pollen, dinocyst and isotope data. JF assembled the data and wrote the paper with input from all coauthors.

Competing interests. The authors declare that they have no conflict of interest.

Acknowledgements. This research was funded through NWO VENI grant no. 863.13.002 to Peter K. Bijl. Jörg Pross acknowledges financial support by Heidelberg University. Stephen J. Gallagher was partly funded by the ARC Basin Genesis Hub. We thank Natasja Welters, Giovanni Dammers and Arnold van Dijk (Utrecht University) and Rineke Gieles, Marcel van der Meer and Ronald van Bommel (Netherlands Institute for Sea Research (NIOZ)) for technical assistance. Wim Hoek (Utrecht University) and Marcel van der Linden and Johan van Heerwaarden (NIOZ) are thanked for help developing the casing technique of sampling. We thank Erica Crouch and an anonymous reviewer for their constructive comments.

Edited by: Luke Mander

Reviewed by: Erica Crouch and one anonymous referee

\section{References}

Abdul Aziz, H., Hilgen, F. J., van Luijk, G. M., Sluijs, A., Kraus, M. J., Pares, J. M., and Gingerich, P. D.: Astronomical climate control on paleosol stacking patterns in the upper Paleocene-lower Eocene Willwood Formation, Bighorn Basin, Wyoming, Geology, 36, 531-534, https://doi.org/10.1130/G24734A.1, 2008.

Agnini, C., Macrì, P., Backman, J., Brinkhuis, H., Fornaciari, E., Giusberti, L., Luciani, V., Rio, D., Sluijs, A., and Speranza, F.: An early Eocene carbon cycle perturbation at $\sim 52.5 \mathrm{Ma}$ in the Southern Alps: Chronology and biotic response, Paleoceanography, 24, PA2209, https://doi.org/10.1029/2008PA001649, 2009.

Archer, V.: Palynology of the Victorian Mines Department Latrobe1 Bore, Otway Basin, Victoria, Monash University, Melbourne, Australia, 1977.

Arditto, P. A.: The Eastern Otway Basin Wangerrip Group revisited using an integrated sequence methodology, Apea J., 35, 372-384, 1995.

Baker, G.: Geology and Physiography of the Moonlight Head District, Victoria, Proc. R. Soc. Victoria, 60, 17-42, 1950.
Baker, G.: The relation of Cyclammina-bearing sediments to the older Tertiary deposits south-east of Princetown, Victoria, Mem. Nat. Museum Melb., 18, 125-134, 1953.

Berggren, W. A. and Pearson, P. N.: A Revised Tropical to Subtropical Paleogene Planktonic Foraminiferal Zonation, J. Foramin. Res., 35, 279-298, https://doi.org/10.2113/35.4.279, 2005.

Bijl, P. K., Schouten, S., Sluijs, A., Reichart, G.-J., Zachos, J. C., and Brinkhuis, H.: Early Palaeogene temperature evolution of the southwest Pacific Ocean, Nature, 461, 776-779, https://doi.org/10.1038/nature08399, 2009.

Bijl, P. K., Houben, A. J. P., Schouten, S., Bohaty, S. M., Sluijs, A., Reichart, G.-J., Sinninghe Damsté, J. S., and Brinkhuis, H.: Transient Middle Eocene Atmospheric $\mathrm{CO}_{2}$ and Temperature Variations, Science, 330, 819-821, https://doi.org/10.1126/science.1193654, 2010.

Bijl, P. K., Pross, J., Warnaar, J., Stickley, C. E., Huber, M., Guerstein, R., Houben, A. J. P., Sluijs, A., Visscher, H., and Brinkhuis, H.: Environmental forcings of Paleogene Southern Ocean dinoflagellate biogeography, Paleoceanography, 26, 1-12, https://doi.org/10.1029/2009PA001905, 2011.

Bijl, P. K., Bendle, J. A. P., Bohaty, S. M., Pross, J., Schouten, S., Tauxe, L., Stickley, C. E., McKay, R. M., Rohl, U., Olney, M., Sluijs, A., Escutia, C., Brinkhuis, H., Klaus, A., Fehr, A., Williams, T., Carr, S. A., Dunbar, R. B., Gonzalez, J. J., Hayden, T. G., Iwai, M., Jimenez-Espejo, F. J., Katsuki, K., Kong, G. S., Nakai, M., Passchier, S., Pekar, S. F., Riesselman, C., Sakai, T., Shrivastava, P. K., Sugisaki, S., Tuo, S., van de Flierdt, T., Welsh, K., and Yamane, M.: Eocene cooling linked to early flow across the Tasmanian Gateway, P. Natl. Acad. Sci. USA, 110, 96459650, https://doi.org/10.1073/pnas.1220872110, 2013a.

Bijl, P. K., Sluijs, A., and Brinkhuis, H.: A magneto- and chemostratigraphically calibrated dinoflagellate cyst zonation of the early Palaeogene South Pacific Ocean, Earth-Sci. Rev., 124, 1-31, https://doi.org/10.1016/j.earscirev.2013.04.010, 2013b.

Bijl, P. K., Brinkhuis, H., Egger, L. M., Eldrett, J. S., Frieling, J., Grothe, A., Houben, A. J. P., Pross, J., Śliwińska, K. K., and Sluijs, A.: Comment on " Wetzeliella and its allies - the 'hole' story: a taxonomic revision of the Paleogene dinoflagellate subfamily Wetzelielloideae" by Williams et al. (2015), Palynology, 6122, 1-7, https://doi.org/10.1080/01916122.2016.1235056, 2016.

Cande, S. C. and Stock, J. M.: Cenozoic reconstructions of the Australia-New Zealand-South Pacific sector of Antarctica, in: Geophysical Monograph Series, 151, 5-17, https://doi.org/10.1029/151GM02, 2004.

Carpenter, R. J., Jordan, G. J., Macphail, M. K., and Hill, R. S.: Near-tropical early eocene terrestrial temperatures at the Australo-Antarctic margin, western Tasmania, Geology, 40, 267270, https://doi.org/10.1130/G32584.1, 2012.

Contreras, L., Pross, J., Bijl, P. K., Koutsodendris, A., Raine, J. I., van de Schootbrugge, B., and Brinkhuis, H.: Early to Middle Eocene vegetation dynamics at the Wilkes Land Margin (Antarctica), Rev. Palaeobot. Palynol., 197, 119-142, https://doi.org/10.1016/j.revpalbo.2013.05.009, 2013.

Contreras, L., Pross, J., Bijl, P. K., O'Hara, R. B., Raine, J. I., Sluijs, A., and Brinkhuis, H.: Southern high-latitude terrestrial climate change during the Palaeocene-Eocene derived from a marine pollen record (ODP Site 1172, East Tasman Plateau), Clim. Past, 10, 1401-1420, https://doi.org/10.5194/cp-10-1401-2014, 2014. 
Cookson, I. C. and Eisenack, A.: Microplankton from the Paleocene Pebble Point Formation, south-western Victoria, P. Roy. Soc. Victoria, 79, 139-146, 1965.

Crouch, E. M.: Environmental Change at the time of the PaleoceneEocene Biotic Turnover, Utrecht University, Utrecht, the Netherlands 2001.

Crouch, E. M. and Brinkhuis, H.: Environmental change across the Paleocene-Eocene transition from eastern New Zealand: a marine palynological approach, Mar. Micropaleontol., 56, 138-160, 2005.

Crouch, E. M., Heilmann-Clausen, C., Brinkhuis, H., Morgans, H. E. G., Rogers, K. M., Egger, H., and Schmitz, B.: Global dinoflagellate event associated with the late Paleocene thermal maximum, Geology, 29, 315-318, 2001.

Crouch, E. M., Willumsen, P. S., Kulhanek, D. K., and Gibbs, S. J.: A revised Paleocene (Teurian) dinoflagellate cyst zonation from eastern New Zealand, Rev. Palaeobot. Palynol., 202, 4779, https://doi.org/10.1016/j.revpalbo.2013.12.004, 2014.

Eglington, C.: Palaeogene Ostracoda (Crustacea) from the Wangerrip Group, Latrobe-1 bore, Otway Basin, Victoria, Australia, Proc. R. Soc. Victoria, 118, 87-111, 2006.

Esplan, W. A.: Electric log correlation of water wells in the Victorian sector of the Otway Basin., in: The Otway Basin of Southeastern Australia, edited by: Wopfner, H. and Douglas, J. G., Geological Surveys of South Australia and Victoria, 251-271, 1971.

Fensome, R. A. and Williams, G. L.: The Lentin and Williams Index of Fossil Dinoflagellates 2004 Edition, 909 pp., Am. Assoc. Strat. Coll. Station, Tex, 2004.

Freeman, K. H. and Hayes, J. M.: Fractionation of carbon isotopes by phytoplankton and estimates of ancient $\mathrm{CO}_{2}$ levels, Global Biogeochem. Cycles, 6, 185-198, 1992.

Frieling, J.: Climate, Carbon Cycling and Marine Ecology during the Paleocene Eocene Thermal Maximum, Utrecht University, Utrecht, the Netherlands, 2016.

Frieling, J., Huurdeman, E. P., Rem, C. C. M., Donders, T. H., Pross, J., Bohaty, S. M., Holdgate, G. R., Gallagher, S. J., McGowran, B., and Bijl, P. K.: Carbon, carbon isotope and dinoflagellate and pollen of the Latrobe-1 and Point Margaret, Victoria, Australia, https://doi.org/10.1594/PANGAEA.886006, created and last access: 2 February 2018.

Gallagher, S. and Holdgate, G.: The palaeogeographic and palaeoenvironmental evolution of a Palaeogene mixed carbonate-siliciclastic cool-water succession in the Otway Basin, Southeast Australia, Palaeogeogr. Palaeocl., 156, 19-50, https://doi.org/10.1016/S0031-0182(99)00130-3, 2000.

Gradstein, F. M., Ogg, J. G., Schmitz, M., and Ogg, G.: The Geologic Time Scale 2012, 2-Volume Set, Elsevier, Elsevier B.V., Amsterdam, the Netherlands, 2012.

Guasti, E., Kouwenhoven, T. J., Brinkhuis, H., and Speijer, R. P. Paleocene sea-level and productivity changes at the southern Tethyan margin (El Kef, Tunisia), Mar. Micropaleontol., 55, 1$17,2005$.

Harris, W. K.: Tertiary stratigraphic palynology, Otway Basin, in: The Otway Basin of Southeastern Australia. Geological Surveys of South Australia and Victoria, edited by: Wopfner, H. and Douglas, J. G., 67-87, 1971.

Harris, W. K.: Basal tertiary microfloras from the Princetown area, Victoria, Australia, Paleontogr. Abteilung B, 75-106, 1965.
Hedges, J. I., Keil, R. G., and Benner, R.: What happens to terrestrial organic matter in the ocean?, Org. Geochem., 27, 195-212, https://doi.org/10.1016/S0146-6380(97)00066-1, 1997.

Holdgate, G. R. and Gallagher, S. J.: Chapter 10: Tertiary, in: Geology of Victoria, 289-324, 2003.

Holdgate, G. R., Rodriquez, C., Johnstone, E. M., Wallace, M. W., and Gallagher, S. J.: The Gippsland Basin Top Latrobe Unconformity and its expression in other Southeast Australia basins, Aust. Pet. Prod. Explor. Assoc. J., 43, 149-173, 2003.

Holdgate, G. R., Sluiter, I. R. K., and Taglieri, J.: Eocene-Oligocene coals of the Gippsland and Australo-Antarctic basins - Palaeoclimatic and palaeogeographic context and implications for the Earliest Cainozoic glaciations, Palaeogeogr. Palaeocl., 472, 236255, https://doi.org/10.1016/j.palaeo.2017.01.035, 2017.

Hollis, C. J., Handley, L., Crouch, E. M., Morgans, H. E. G., Baker, J. A., Creech, J., Collins, K. S., Gibbs, S. J., Huber, M., Schouten, S., Zachos, J. C., and Pancost, R. D.: Tropical sea temperatures in the high-latitude South Pacific during the Eocene, Geology, 37, 99-102, https://doi.org/10.1130/G25200A.1, 2009.

Hollis, C. J., Taylor, K. W. R., Handley, L., Pancost, R. D., Huber, M., Creech, J. B., Hines, B. R., Crouch, E. M., Morgans, H. E. G., Crampton, J. S., Gibbs, S., Pearson, P. N., and Zachos, J. C.: Early Paleogene temperature history of the Southwest Pacific Ocean: Reconciling proxies and models, Earth Planet. Sci. Lett., 349-350, 53-66, https://doi.org/10.1016/j.epsl.2012.06.024, 2012.

Hollis, C. J., Hines, B. R., Littler, K., Villasante-Marcos, V., Kulhanek, D. K., Strong, C. P., Zachos, J. C., Eggins, S. M., Northcote, L., and Phillips, A.: The Paleocene-Eocene Thermal Maximum at DSDP Site 277, Campbell Plateau, southern Pacific Ocean, Clim. Past, 11, 1009-1025, https://doi.org/10.5194/cp11-1009-2015, 2015.

Huber, B. T. and Quillévéré, F.: Revised Paleogene Planktonic Foraminiferal Biozonation for the Austral Realm, J. Foraminifer. Res., 35, 299-314, https://doi.org/10.2113/35.4.299, 2005.

Keating, K.: The lithostratigraphy, palynology and sequence stratigraphy of the Pebble Point Formation, La Trobe University, Bundoora, Victoria, 1993.

Kennett, J. P.: Cenozoic evolution of Antarctic glaciation, the circum-Antarctic Ocean, and their impact on global paleoceanography, J. Geophys. Res., 82, 3843-3860, https://doi.org/10.1029/JC082i027p03843, 1977.

Kennett, J. P. and Stott, L. D.: Abrupt deep-sea warming, palaeoceanographic changes and benthic extinctions at the end of the Palaeocene, Nature, 353, 225-229, 1991.

Kirtland Turner, S. and Ridgwell, A.: Development of a novel empirical framework for interpreting geological carbon isotope excursions, with implications for the rate of carbon injection across the PETM, Earth Planet. Sci. Lett., 435, 1-13, https://doi.org/10.1016/j.epsl.2015.11.027, 2016.

Lourens, L. J., Sluijs, A., Kroon, D., Zachos, J. C., Thomas, E., Röhl, U., Bowles, J., and Raffi, I.: Astronomical pacing of late Palaeocene to early Eocene global warming events, Nature, 435, 1083-1087, 2005.

Macphail, M. K., Alley, F., Truswell, E. M., and Sluiter, I. R. K.: Early Tertiary vegetation: evidence from spores and pollen, in: History of Australian Vegetation: Cretaceous to Recent, edited by: Hill, R. S., Cambridge University Press, Cambridge, 189261, 1994. 
McGowran, B.: Two Paleocene Foraminiferal Faunas from the Wangerrip Group, Pebble Point Coastal Section, Western Victoria, Proc. R. Soc. Victoria, 79, 9-74, 1965.

McGowran, B.: Late Paleocene in the Otway Basin: Biostratigraphy and Age of Key Microfaunas, Trans. R. Soc. Victoria, 94, 1-14, 1970.

McGowran, B.: Early Tertiary biostratigraphy in southern Australia: a progress report, in: The Crespin Volume: Essays in Honour of Irene Crespin, edited by: Belford, D. J. and Scheibnerova, V., Bureau Mineral Resources Australia, 83-95, 1978.

McGowran, B.: Maastrichtian and early Cainozoic, southern Australia: foraminiferal biostratigraphy, in: The Cainozoic of the Australian region, edited by: Williams, M. A. J., de Deckker, P., and Kershaw, A. P., Geological Society of Australia Special Publication, Sydney, Australia, 79-98, 1991.

McGowran, B. and Hill, R. S.: Cenozoic climatic shifts in Southern Australia, T. Roy. Soc. South Aust., 139, 19-37, https://doi.org/10.1080/03721426.2015.1035215, 2015.

McGowran, B., Holdgate, G. R., Li, Q., and Gallagher, S. J.: Cenozoic stratigraphic succession in southeastern Australia, Aust. J. Earth Sci., 51, 459-496, https://doi.org/10.1111/j.14000952.2004.01078.x, 2004.

McInerney, F. A. and Wing, S. L.: The Paleocene-Eocene thermal maximum: a perturbation of carbon cycle, climate, and biosphere with implications for the future, Annu. Rev. Earth Planet. Sci., 39, 489-516, 2011.

Morgans, H. E. G., Beu, A. G., Cooper, R. A., Crouch, E. M., Hollis, C. J., Jones, C. M., Raine, J. I., Strong, C. P., Wilson, G. J., and Wilson, G. S.: Paleogene, in: The New Zealand Geological Timescale, edited by: Cooper, R. A., Institute of Geological and Nuclear Sciences Monograph, 22, 124-163, 2004.

Murphy, B. H., Farley, K., and Zachos, J. C.: An extraterrestrial 3 He-based timescale for the Paleocene-Eocene thermal maximum (PETM) from Walvis Ridge, IODP Site 1266, Geochim. Cosmochim. Ac., 74, 5098-5108, 2010.

Nicolo, M. J., Dickens, G. R., Hollis, C. J., and Zachos, J. C.: Multiple early Eocene hyperthermals: Their sedimentary expression on the New Zealand continental margin and in the deep sea, Geology, 35, 699-702, https://doi.org/10.1130/G23648A.1, 2007.

Partridge, A. D.: Late Cretaceous to Tertiary Geological Evolution of the Gippsland Basin, Victoria, La Trobe University, Bundoora, Victoria, Australia, 1999.

Partridge, A. D.: Late Cretaceous-Cenozoic palynology zonations Gippsland Basin [chart], in: Australian Mesozoic and Cenozoic Palynology Zonations, edited by: Monteil, E., Geoscience Australia, 2006.

Pross, J., Contreras, L., Bijl, P. K., Greenwood, D. R., Bohaty, S. M., Schouten, S., Bendle, J. A. P., Röhl, U., Tauxe, L., Raine, J. I., Huck, C. E., Van De Flierdt, T., Jamieson, S. S. R., Stickley, C. E., Van De Schootbrugge, B., Escutia, C., Brinkhuis, H., Dotti, C. E., Klaus, A., Fehr, A., Williams, T., Carr, S. A., Dunbar, R. B., Gonzàlez, J. J., Hayden, T. G., Iwai, M., JimenezEspejo, F. J., Katsuki, K., Soo Kong, G., Mckay, R. M., Nakai, M., Olney, M. P., Passchier, S., Pekar, S. F., Riesselman, C. R., Sakai, T., Shrivastava, P. K., Sugisaki, S., Tuo, S., Welsh, K., and Yamane, M.: Persistent near-tropical warmth on the Antarctic continent during the early Eocene epoch, Nature, 487, 73-77, https://doi.org/10.1038/nature11300, 2012.
Röhl, U., Westerhold, T., Bralower, T. J., and Zachos, J. C.: On the duration of the Paleocene-Eocene thermal maximum (PETM), Geochemistry, Geophys. Geosyst., 8, 1-13, https://doi.org/10.1029/2007GC001784, 2007.

Sijp, W. P., England, M. H., and Huber, M.: Effect of the deepening of the Tasman Gateway on the global ocean, Paleoceanography, 26, 1-18, https://doi.org/10.1029/2011PA002143, 2011.

Sijp, W. P., von der Heydt, A. S., Dijkstra, H. A., Flögel, S., Douglas, P. M. J. J., and Bijl, P. K.: The role of ocean gateways on cooling climate on long time scales, Glob. Planet. Change, 119, 1-22, https://doi.org/10.1016/j.gloplacha.2014.04.004, 2014.

Sijp, W. P., von der Heydt, A. S., and Bijl, P. K.: Model simulations of early westward flow across the Tasman Gateway during the early Eocene, Clim. Past, 12, 807-817, https://doi.org/10.5194/cp-12-807-2016, 2016.

Sluijs, A. and Brinkhuis, H.: A dynamic climate and ecosystem state during the Paleocene-Eocene Thermal Maximum: inferences from dinoflagellate cyst assemblages on the New Jersey Shelf, Biogeosciences, 6, 1755-1781, https://doi.org/10.5194/bg-61755-2009, 2009.

Sluijs, A. and Dickens, G. R.: Assessing offsets between the $\delta 13 \mathrm{C}$ of sedimentary components and the global exogenic carbon pool across early Paleogene carbon cycle perturbations, Global Biogeochem. Cycles, 26, 1-14, https://doi.org/10.1029/2011GB004224, 2012.

Sluijs, A., Brinkhuis, H., Stickley, C. E., Warnaar, J., Williams, G. L., and Fuller, M.: Dinoflagellate cysts from the Eocene/Oligocene transition in the Southern Ocean; results from ODP Leg 189, Proc. Ocean Drill. Program Sci. Results, 189, 1-42, 2003.

Sluijs, A., Bowen, G. J., Brinkhuis, H., Lourens, L. J., and Thomas, E.: The Palaeocene-Eocene Thermal Maximum super greenhouse: Biotic and geochemical signatures, age models and mechanisms of global change, in: Deep-Time Perspectives on Climate Change: Marrying the Signal from Computer Models and Biological Proxies, edited by: Williams, M., Haywood, A. M., Gregory, F. J., and Schmidt, D. N., Geol. Soc. Spec. Publ., The Geological Society, London, 323-349, 2007.

Sluijs, A., Bijl, P. K., Schouten, S., Röhl, U., Reichart, G.-J., and Brinkhuis, H.: Southern ocean warming, sea level and hydrological change during the Paleocene-Eocene thermal maximum, Clim. Past, 7, 47-61, https://doi.org/10.5194/cp-7-472011, 2011.

Sluijs, A., Zeebe, R. E., Bijl, P. K., and Bohaty, S. M.: A middle Eocene carbon cycle conundrum. Nat. Geosci., 6, 429-434, 2013.

Stilwell, J. D.: Macropalaeontology of the TrochocyathusTrematotrochus band (Paleocene/Eocene boundary), Dilwyn Formation, Otway Basin, Victoria. Alcheringa An Australas, J. Palaeontol., 27, 245-275, https://doi.org/10.1080/03115510308619107, 2003.

Stover, L. and Partridge, A. D.: Tertiary and Late Cretaceous spores and pollen from the Gippsland Basin, southeastern Australia, Proc. R. Soc. Victoria, 85, 237-286, 1973.

Taylor, D. J.: Biostratigraphic log Latrobe No. 1 bore, Department of Mines of Victoria, Melbourne, 1964.

Taylor, D. J.: Preservation, composition, and significance of Victorian Lower Tertiary "Cyclammina faunas.", Proc. R. Soc. Victoria, 78, 143-160, 1965. 
Utescher, T. and Mosbrugger, V.: The Palaeoflora Database, available at: http://www.palaeoflora.de/, last access: 22 December 2015.

Wade, B. S., Pearson, P. N., Berggren, W. A., and Pälike, H.: Review and revision of Cenozoic tropical planktonic foraminiferal biostratigraphy and calibration to the geomagnetic polarity and astronomical time scale, Earth-Sci. Rev., 104, 111-142, https://doi.org/10.1016/j.earscirev.2010.09.003, 2011.

White, J.: Composite Well Log Latrobe No.1 Water Bore, Department of Mines of Victoria, Melbourne, 1963.

Wilson, G. J.: Paleocene and Eocene Dinoflagellate Cysts from Waipawa, Hawkes Bay, New Zealand, New Zeal. Geol. Surv. Paleontol. Bull., 57, 1-96, 1988.
Witkowski, J., Bohaty, S. M., Edgar, K. M., and Harwood, D. M.: Rapid fluctuations in mid-latitude siliceous plankton production during the Middle Eocene Climatic Optimum (ODP Site 1051, western North Atlantic), Mar. Micropaleontol., 106, 110-129, https://doi.org/10.1016/j.marmicro.2014.01.001, 2014.

Zeebe, R. E., Ridgwell, A., and Zachos, J. C.: Anthropogenic carbon release rate unprecedented during the past 66 million years, Nat. Geosci., 9, 325-329, https://doi.org/10.1038/ngeo2681, 2016. 